\title{
LONG-TERM EFFECTS OF A PRESCRIBED FIRE REGIME ON TREE SEEDLING DENSITY IN AN OAK-HICKORY WOODLAND
}

\author{
A thesis presented to the faculty of the Graduate School \\ University of Missouri - Columbia
}

\author{
In Partial Fulfillment \\ Of the Requirements for the Degree \\ Master of Science in Forestry
}

By

CHRISTINE F. STEINWAND

Dr. Rose-Marie Muzika, Thesis Supervisor

July 2014 
The undersigned, appointed by the Dean of the Graduate School, have examined the thesis entitled:

LONG-TERM EFFECTS OF A PRESCRIBED FIRE REGIME ON TREE SEEDLING DENSITY IN AN OAK-HICKORY WOODLAND

presented by Christine F. Steinwand

a candidate for the degree of Master of Science in Forestry, and hereby certify that, in their opinion, it is worthy of acceptance.

Dr. Rose-Marie Muzika

Dr. Francisco Aguilar

Dr. Candace Galen

Dr. Grant Elliott 


\section{DEDICATION}

To grandma and grandpa, mom, mom, dad, and everyone else that has loved and believed in me. 


\section{ACKNOWLEDGEMENTS}

I want to thank Rose-Marie for her belief in my abilities, for granting me the opportunity to work on this project, and for the invaluable personal and professional guidance she has provided. I want to thank my committee members for their various contributions over the years, both in the classroom and outside it. Thanks to the USDA National Needs Fellowship Program for providing the funding, to the University of Missouri faculty and staff (especially LC) for their guidance and education, and to my partners at the National Park Service - especially my colleagues and surrogate family at the Ozark National Scenic Riverways. I could not have done this without the inspiration and dedication of Susan, Dan, and Angela, and their passion for fire ecology and their belief in what they do for Missouri and conservation. I also owe an immense thank-you to my labmates and fellow graduate students at Mizzou, without whom I would not have received life-saving feedback, friendship, and support during some of the most challenging years of my life. Cheers. 


\section{TABLE OF CONTENTS}

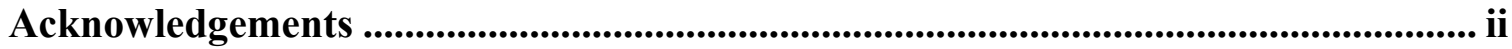

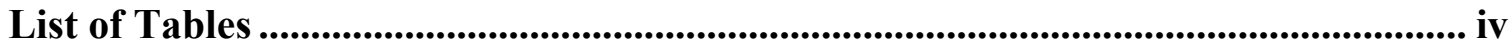

List of Figures................................................................................................................................... vi

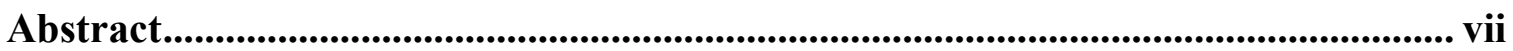

Literature Review: Understory Tolerance, Fire, and Oaks .......................................1

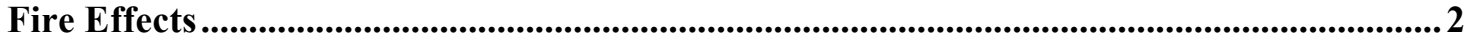

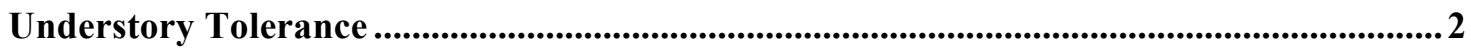

Synthesis: Fire Effects and Understory Tolerance ...................................................................... 4

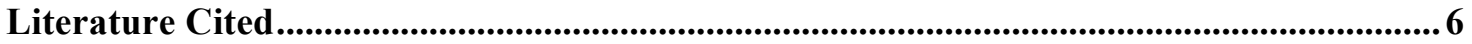

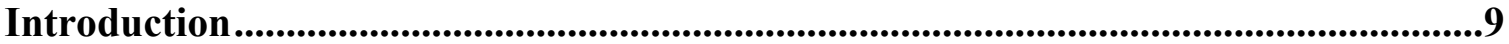

Fire Management in the Missouri Ozarks ............................................................................... 12

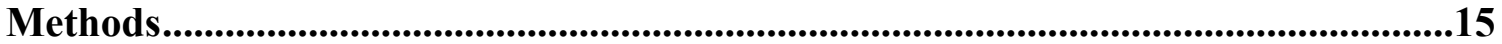

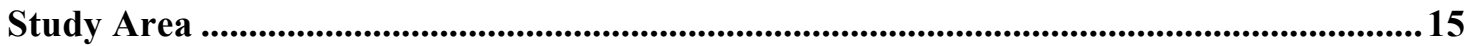

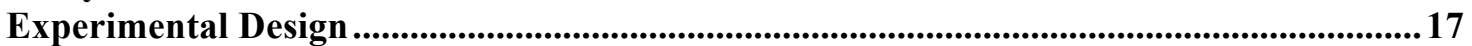

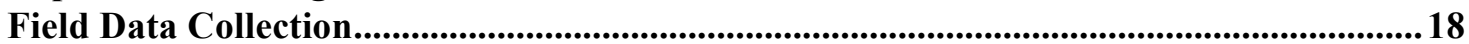

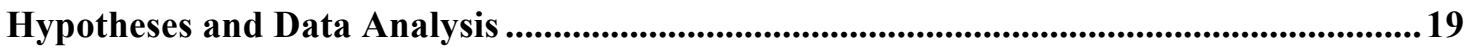

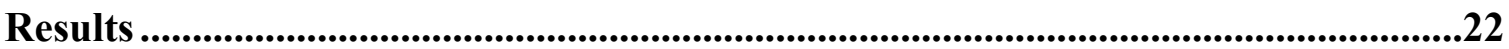

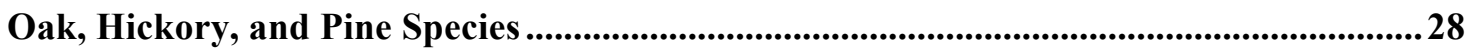

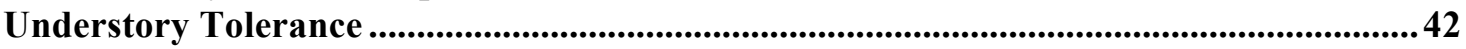

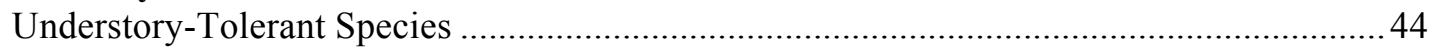

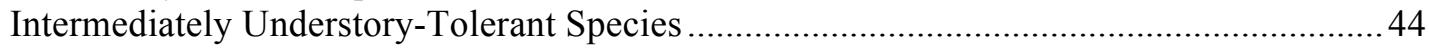

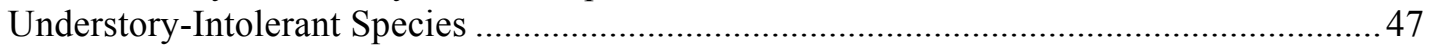

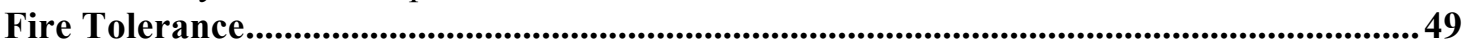

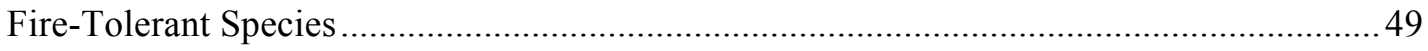

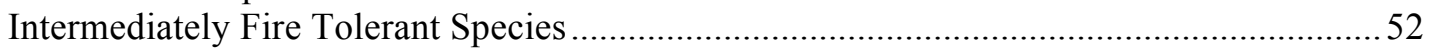

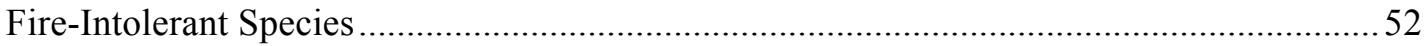

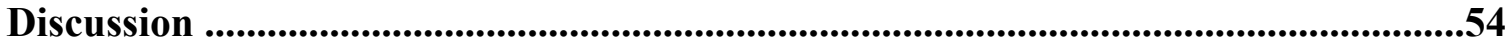

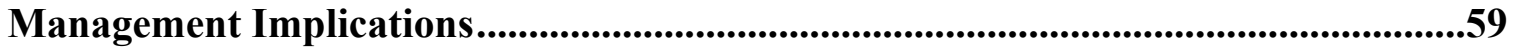

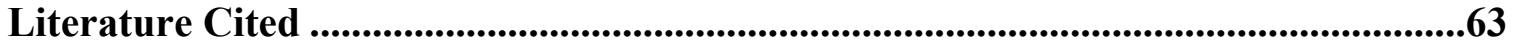

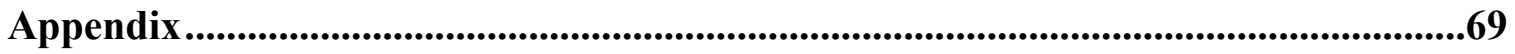

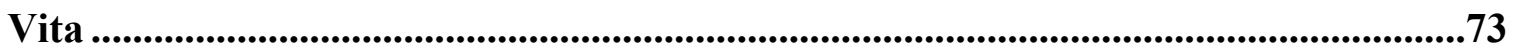




\section{LIST OF TABLES}

Table 1. Common names and understory and fire tolerance ratings for 30 sampled tree species at the Ozark National Scenic Riverways. Understory and fire tolerances of seedlings belonging to each species were based on information provided by several authors associated with the US Forest Service Fire Effects Information System Database

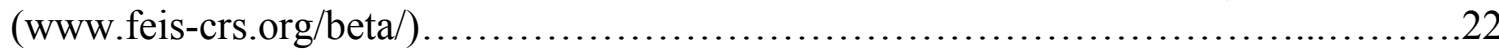

Table 2. Mean seedling (stem) density ha-1 and standard error (SE) by tolerance, natural

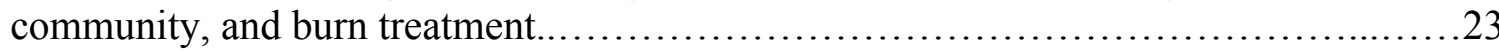

Table 3. t-values and Tukey-Kramer adjusted P-values for the comparison of seedling density for all species, between xeric and mesic woodlands, with the continued use of fire. For all comparisons, $\alpha=0.05$.

Table 4. $\mathrm{t}$-values and Tukey-Kramer adjusted P-values for the comparison of seedling density of all species after repeated fire in xeric and mesic woodlands. For all

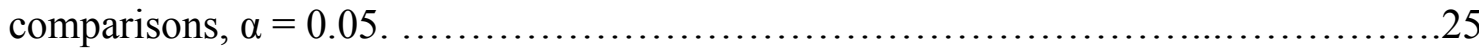

Table 5. t-values and Tukey-Kramer adjusted P-values for the comparison of seedling density for hickory species, between xeric and mesic woodlands, with the continued use of fire. For all comparisons, $\alpha=0.05$.

Table 6. t-values and Tukey-Kramer adjusted P-values for the comparison of seedling density of each hickory species after repeated fire in xeric and mesic woodlands. For all comparisons, $\alpha=0.05$.

Table 7. t-values and Tukey-Kramer adjusted P-values for the comparison of seedling density for shortleaf pine, between xeric and mesic woodlands, with the continued use of fire. For all comparisons, $\alpha=0.05$.

Table 8. t-values and Tukey-Kramer adjusted P-values for the comparison of seedling density of shortleaf pine after repeated fire in xeric and mesic woodlands. For all comparisons, $\alpha=0.05$.

Table 9. t-values and Tukey-Kramer adjusted P-values for the comparison of seedling density for oak species, between xeric and mesic woodlands, with the continued use of

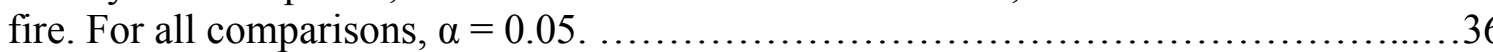

Table 10. t-values and Tukey-Kramer adjusted P-values for the comparison of seedling density of white oak group species after repeated fire in xeric and mesic woodlands. For all comparisons, $\alpha=0.05$.

Table 11. t-values and Tukey-Kramer adjusted P-values for the comparison of seedling density of red oak group species after repeated fire in xeric and mesic woodlands. For all comparisons, $\alpha=0.05$. 
Table12. t-values and Tukey-Kramer adjusted P-values for understory tolerance, when comparing xeric and mesic woodlands, after repeated fire. For all comparisons, $\alpha=0.05$.

Table13. t-values and Tukey-Kramer adjusted P-values for understory tolerance, when comparing repeated fires in xeric or mesic woodlands. For all comparisons, $\alpha=0.05 \ldots .45$

Table 14. t-values and Tukey-Kramer adjusted P-values for fire tolerance, when comparing xeric and mesic woodlands, after repeated fire. For all comparisons, $\alpha=0.05$.

Table 15. t-values and Tukey-Kramer adjusted P-values for fire tolerance, when comparing repeated fires in xeric or mesic woodlands. For all comparisons, $\alpha=0.05$.

Table A1. List of the 30 species used in this study, including the taxonomic authorities and respective FEIS Database authors (contributors). Taxonomic authorities were crosschecked with the USDA NRCS Plants Database (http://plants.usda.gov) for accuracy, as authorities are commonly updated. .68

Table A2. Type III sum of squares tests for fixed effects used to model overall seedling density. For all comparisons, $\alpha=0.05$.

Table A3. Type III sum of squares tests for fixed effects used to model understory intolerant seedling density. For all comparisons, $\alpha=0.05$.

Table A4. Type III sum of squares tests for fixed effects used to model intermediately

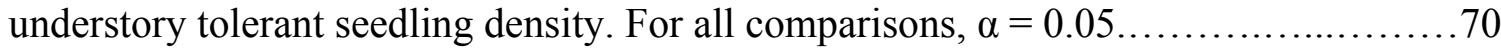

Table A5. Type III sum of squares tests for fixed effects used to model understory tolerant seedling density. Effects for this group were modeled using a rank

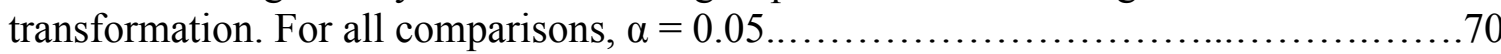

Table A6. Type III sum of squares tests for fixed effects used to model fire-intolerant seedling density. Effects for this group were modeled using a rank transformation. For all

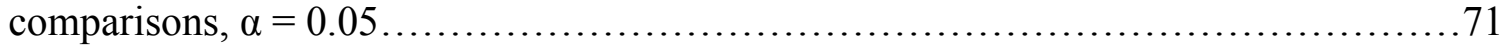

Table A7. Type III sum of squares tests for fixed effects used to model intermediately fire

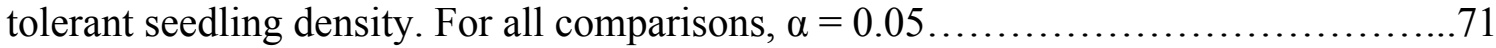

Table A8. Type III sum of squares tests for fixed effects used to model fire-tolerant

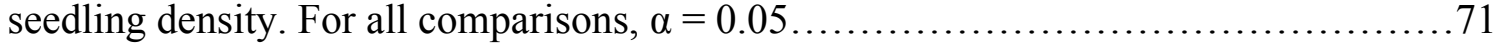




\section{LIST OF FIGURES}

Figure 1. Mean seedling density ha-1 per burn treatment in xeric and mesic woodlands at the Ozark National Scenic Riverways............................................26

Figure 2. Mean seedling density ha-1 in xeric and mesic woodlands of a.) bitternut hickory, b.) pignut hickory, c.) black hickory, and d.) mockernut hickory at ONSR.......31

Figure 3. Mean seedling density ha-1 of shortleaf pine in xeric and mesic woodlands at ONSR

Figure 4. Mean seedling density ha-1, in xeric and mesic woodlands, for a) white oak, b.) chinkapin oak, and c.) post oak (leucobalanus) at ONSR ...............................

Figure 5. Mean seedling density ha-1 of a.) scarlet oak, b.) northern red oak, and c.) black oak (erythrobalanus), in xeric and mesic woodlands at ONSR .........................40

Figure 6. Proportions of understory-tolerant, intermediately-tolerant, and understoryintolerant seedling species in a.) xeric and b.) mesic woodlands at ONSR after increasing number of burns. In both natural communities, understory-intolerant species comprised the greatest proportion of all seedlings sampled....................................42

Figure 7. Mean seedling density ha-1 in xeric and mesic woodlands for a.) understorytolerant, b.) intermediately-tolerant, and c.) understory-intolerant seedling species, across increasing number of prescribed burns, at OSNR .................................4

Figure 8. Proportions of fire-tolerant, intermediately-tolerant, and fire-intolerant seedling species in a.) xeric and b.) mesic woodlands at ONSR after increasing number of burns. In both natural communities, fire-tolerant species comprised the greatest proportion of seedlings.

Figure 9. Mean seedling density ha-1 in xeric and mesic woodlands for a.) fire-tolerant, b.) intermediately-tolerant, and c.) fire-intolerant seedling species, across increasing number of prescribed burns, at OSNR 


\begin{abstract}
The mesophication of oak-hickory forests and woodlands, in combination with the decline of dominant overstory oaks, is becoming an important management issue in the Central Hardwoods Region. Suppression of understory-tolerant species, as well as the recruitment of oaks, hickory, and shortleaf pine is a common land-management goal across the Central Hardwoods, including the Missouri Ozarks. After decades of fire suppression, land managers in the Missouri Ozark Highlands began applying prescribed fire to promote the regeneration of oak and hickory species, and to prevent the recruitment of mesophytic understory species into the overstory. In this study, 13 years of prescribed fire data were examined to determine the response of oak, hickory, and shortleaf pine tree seedling density, as well as the densities of various understory and fire tolerant species, after repeated low- to moderate-intensity periodic burns at the Ozark National Scenic Riverways. Seedling density data were collected pre-burn, then after 1, 2, 3 , or 4 burns, in xeric and mesic woodland plots. Seedling density was greater in mesic woodlands than xeric woodlands, overall. Oak, hickory, and shortleaf pine seedling densities did not change due to the periodic prescribed fire regime. In xeric woodlands, seedling density increased for both intermediately understory-tolerant and understoryintolerant seedlings, while fire-tolerant species seedling density increased. No long-term changes were significant in mesic woodlands, suggesting that prescribed fire may be affecting xeric woodlands more intensely than mesic areas, and that other ecological factors, not fire, are likely keeping understory-tolerant species at low densities. Since mesophication does not appear to be a prominent issue, and fire is disproportionately affecting xeric woodlands, recruitment may be improved by increasing the fire return
\end{abstract}


interval to allow seedling growth. 


\section{LITERATURE REVIEW: UNDERSTORY TOLERANCE, FIRE, AND OAKS}

Oak (Quercus) and pine (Pinus) species have been a growing presence in eastern North America for thousands of years, dating from the beginning of the Holocene epoch 10,000 YBP (Abrams 1996). At the end of the last glacial period, climatic conditions shifted to a warmer, dryer environment (Watts 1979), which allowed fires - both natural and anthropogenic - to burn more regularly across the landscape (Abrams 1996, Delcourt and Delcourt 1997, Nowacki and Abrams 2008). These conditions, in turn, led to the dense oak, pine, and other hardwood forest mosaics depicted by early European settlers (Abrams 1992, Rentch and Hicks 2005). According to historical accounts, settled areas were commonly dominated by white oak (Quercus alba L.) and other oak species; pollen records also indicate large numbers of reproducing oaks across eastern forest areas (Russell 1980, Abrams 1996, Rentch et al. 2003).

Although a lack of oak regeneration has been consistently recorded since the decades following European settlement (Rentch et al. 2003, Knoot et al. 2010), initial land management - increased fire frequency, for example - expanded the range of dominant oaks in the eastern deciduous forest. This change took place most notably on xeric and nutrient-deficient sites, where oaks were able to replace and outcompete previous vegetation (Abrams 1996). These results were short-lived, however, and significant oak regeneration has not occurred across much of the eastern forest since settlement (Knoot et al. 2010). Several factors have likely contributed to this decline, but the most culpable relate to a change in the disturbance regime of oak forests, including shifting harvesting practices (Knoop et al. 2010), fire suppression (Abrams 1996, Rentch 
et al. 2003, Chapman et al. 2006, Alexander et al. 2008), and fluctuations in herbivore populations (McArthur et al. 1991, Abrams 1996). Of these, fire suppression is most commonly believed to have contributed most strongly to recent oak decline (Abrams 1998, Abrams 2003, Dey and Hartman 2005, Abrams and Steiner 2013).

\section{Fire Effects}

Although there are direct effects of fire on individual trees, these impacts vary depending on species and tree age (Abrams 2003). Oaks and pines, for example, are mostly fire-tolerant as adults; bark on mature trees is relatively thick, and cambium damage is usually limited during low- to moderate-intensity fires (Burton et al. 2011);

fires can actually spur increased growth in remaining released trees (Anning and McCarthy 2013). As seedlings, all species are likely to be top-killed during almost any surface fire; thus, seedling survival is not directly related to the application of fire. Fire is, however, directly responsible for creating several conditions that are necessary for the successful growth and regeneration of oak and pine seedlings, as well as those of other fire-tolerant species, like hickories (Carya). Fire can ready a seedbed for oak and pine germinants by enhancing soil fertility (Glasgow and Matlack 2006), remove litter to improve the likelihood of germination for several fire-tolerant tree species (Burton et al. 2011), and, most importantly, reduce the amount of competition for light resources (Blake and Schutte 2000, Hutchinson et al. 2012).

\section{Understory Tolerance}

Oaks are generally regarded as moderately shade tolerant to shade intolerant (Burns and Honkala 1990, Hutchinson et al. 2012, Abrams and Steiner 2013), and, 
therefore, are classified as early-successional species. The use of shade tolerance as the primary characteristic describing the successional potential of a species does not, however, fully address why oaks or other sseedlings are unable to persist and successfully regenerate in low-light and/or crowded conditions (Finegan 1984). Although it is true that light interception and efficient photosynthesis are critical components of how plants are able to survive and become reproductive in a given area (Valladares and Niinemets 2008), other interacting factors, such as chemical and structural differences and the growth patterns of individuals of different species, are often overlooked or reviewed separately from investigations of shade tolerance. Without understanding an array of understory conditions that impact oaks and other species, in addition to light availability, critical components involved in the prediction of forest successional pathways are missing (Finegan 1984, Kobe et al. 1995).

At low levels of light - about $4 \%$ reaching the ground below a canopy - all tree seedlings struggle to survive, regardless of their supposed shade tolerance. Most examinations of shade tolerance use this level of light as a base. Above $4 \%$ light, growth rates of shade-intolerant species actually exceed those of shade-tolerant species; this fact has muddled the issue of light interception and growth. Below $2 \%$ light at the ground surface, a more realistic percentage for a crowded canopy, shade tolerant species do have higher growth rates (Walters and Reich 1996). What this means is that another issue has been greatly overlooked: shade tolerance is most meaningful when combined with information regarding the tradeoff between growth and respiration in a species when it is in a sub-optimal growing condition. The combination of the tolerance of low-light conditions with the carbon utilization strategy and morphology of a species are more 
appropriate for understanding true understory tolerance (Kobe et al. 1995, Valladares and Niinemets 2008).

Oak species, unlike other, more understory-tolerant species, are not plastic in terms of their carbon-use response to low-light versus sufficient-light conditions (Kubiske et al. 1996, Alexander et al. 2008, Valladares and Niinemets 2008). Species that are typically classified as shade-tolerant, such as those belonging to the genus Acer, are able to reduce their respiration rates in low-light conditions, thereby more efficiently fixing carbon. Oak species, in particular, are not plastic in this way; respiration rates remain high, regardless of the amount of light reaching the leaf surface (Loach 1967, Kubiske et al. 1996, Valladares and Niinemets 2008). Classically shade-tolerant species also have different individual leaf morphology than species considered to be shadeintolerant. Oaks, in particular, have thick leaves (Abrams and Kubiske 1990), and direct much of the fixed carbon into defensive tannins (Abrams 1996); these, in tandem with the inability to adjust respiration rates, results in higher stress and mortality for understory intolerant species, including oaks. Thus, understory tolerant species have more efficient respiration and a more responsive morphology, and can therefore survive more effectively below a closed canopy. This is a truer characterization of understory tolerance than the sole response to light, and is what is used in this thesis to examine seedling density for oak and other species.

\section{Synthesis: Fire Effects and Understory Tolerance}

Oak trees are not able to reduce respiration and carbon fixation rates under lowlight conditions, rendering their growth slower and highly inefficient compared to species that are able to reduce respiration. Thus, oaks that are grown in areas in combination with 
mesophytic, understory-tolerant species are often outcompeted because of their inability to sustain their high growth rates (Abrams 1992, Nowacki and Abrams 2008). This indicates that one of the primary roles of fire in oak-dominated ecosystems is to reduce competition that is understory tolerant, thereby releasing oaks (and other understoryintolerant species, like pines) from species that are able to more efficiently fix carbon at low light levels (Rentch et al. 2003). Applying fire in systems where understory tolerant species have already become large enough to be susceptible to fire, thereby thinning the midstory and ground layers, may allow oak seedlings to persist and survive more successfully than understory tolerant species. This is the primary goal of land managers who use prescribed burning to restore and preserve oak-pine and oak-hickory woodlands. 


\section{LITERATURE CITED}

Abrams, M.D. 1992. Fire and the development of oak forests. BioScience 42(5): 346-353.

Abrams, M.D. 1996. Distribution, historical development and ecophysiological attributes of oak species in the eastern United States. Ann. Sci. For. 53: 487-512.

Abrams, M.D. 1998. The red maple paradox. BioScience 48: 355-364.

Abrams, M.D. 2003. Where has all the white oak gone? BioScience 53: 927-939.

Abrams, M.D. and M.E. Kubiske. 1990. Leaf structural characteristics of 31 hardwood and conifer tree species in central Wisconsin: influence of light regime and shadetolerance rank. For. Ecol. Manage. 31: 245-253.

Abrams, M.D. and Steiner, K.C. 2013. Long-term seedling height growth and compositional changes following logging and wildfire in a central Pennsylvania oak forest. Castanea 78(4): 256-265. doi:10.2179/13-016.

Alexander, H.D., Arthur, M.A., Loftis, D.L., and S.R. Green. 2008. Survival and growth of upland oak and co-occurring competitor seedlings following single and repeated prescribed fires. For. Ecol. Manage. 256: 1021-1030.

Anning, A.K. and B.C. McCarthy. 2013. Long-term effects of prescribed fire and thinning on residual tree growth in mixed-oak forests of southern Ohio.

Ecosystems 16: 1473-1486.

Burns, R.M., and Honkala, B.H. Technical Coordinators. 1990. Silvics of North America. Vol. 2. Hardwoods. US. Dep. Agric. Agric. Handb. 654pp.

Burton, J.A., Hallgren, S.W., Fuhlendorf, S.D., and Leslie, D.M. Jr. 2011. Understory response to varying fire frequencies after 20 years of prescribed burning in an upland oak forest. Plant Ecol. 212: 1513-1525. 
Chapman, R.A., Heitzman, E., and M.G. Shelton. 2006. Long-term changes in forest structure and species composition of an upland oak forest in Arkansas. For. Ecol. Manage. 236: 85-92.

Dey, D.C. and Hartman, G. 2005. Returning fire to Ozark Highland forest ecosystems: effects on advance regeneration. For. Ecol. Manage. 217(1): 37-53. doi:10.1016/j.foreco.2005.05.002.

Delcourt, H.R. and P.A. Delcourt. 1997. Pre-Columbian native American use of fire on southern Appalachian landscapes. Cons Bio 11: 1010-1014.

Finegan, B. 1984. Forest succession. Nature 312: 109-114.

Glasgow, L.S. and G.R. Matlack. 2007. Prescribed burning and understory composition in a temperate deciduous forest, Ohio, USA. For. Ecol. Manage. 238: 54-64.

Hutchinson, T.F., Long, R.P., Rebbeck, J., Sutherland, E.K., and Yaussy, D.A. 2012. Repeated prescribed fires alter gap-phase regeneration in mixed-oak forests. Can. J. For. Res. 42: 303-314. doi:10.1139/X11-184.

Knoot, T.G., Shulte, L.A., Tyndall, J.C., and B.J. Palik. 2010. The state of the system and steps toward resilience of disturbance-dependent oak forests. Ecol and Soc. 15(4): 5 [online] http://www.ecologyandsociety.org/vol15/iss4/art5/.

Kobe, R.K., Pacala, S.W., Silander, J.A., Jr., and C.D. Canham. 1995. Juvenile tree survivorship as a component of shade tolerance. Ecol. App. 5(2): 517-532.

Kubiske, M.E., Abrams, M.D., and S.A. Mostoller. 1996. Stomatal and nonstomatal limitations of photosynthesis in relation to the drought and shade tolerance of tree species in open and understory environments. Trees 11: 76-82. 
Loach, K. 1967. Shade tolerance in tree seedlings. New Phytol. 66: 607-621.

McArthur, C., Hagerman, A.E., and C.T. Robbines. 1991. Physiological strategies of mammalian herbivores against plant defenses. In: Plant Defenses Against Mammalian Herbivory (R.T. Palo and C.T. Robbins, ed.s.), CRC Press, Boca Raton, FL.

Nowacki, G.J. and Abrams, M.D. 2008. The demise of fire and "mesophication" of forests in the eastern United States. BioScience 58(2): 123-138. doi:10.1641/B580207.

Rentch, J.S. and R.R. Hicks, Jr. 2005. Changes in presettlement forest composition for five areas in the Central Hardwood Forest, 1784-1990. Nat Areas J. 25(3): 228238.

Rentch, J.S., Fajvan, M.A., and R.R. Hicks, Jr. 2003. Oak establishment and canopy accession strategies in five old-growth stands in the central hardwood forest region. For. Ecol. Manage.

Russell, E.W. 1980. Vegetational change in northern New Jersey from precolonization to the present: a polynological interpretation. Bull. Torrey Bot. Club 107: 432-446.

Valladares, F. and U. Niinemets. 2008. Shade tolerance, a key plant feature of complex nature and consequences. Annu. Rev. Ecol. Evol. Syst. 39: 237-257.

Walters, M.B. and P.B. Reich. 1996. Are shade tolerance, survival, and growth linked? Low light and nitrogen effects on hardwood seedlings. Ecol. 77: 841-853.

Watts, W.A. 1979. Late Quaternary vegetation of the central Appalachian and the New Jersey coastal plain. Ecol Monogr 49: 427-469. 


\section{INTRODUCTION}

Anthropogenic and natural fires have been an integral formative factor in woodlands and forests of eastern North America for thousands of years (Pyne et al. 1996, Delcourt 2004, Burton et al. 2011). The rise of oak-dominated hardwood ecosystems within the Eastern Deciduous Forest has been largely attributed to historic fire regimes, primarily of Native American origin (Abrams 1992). In the Central Hardwoods region,

fires maintained several landscapes that supported fire-tolerant vegetation and wildlife, including prairies, savannas, open oak and pine woodlands, and oak-pine forests (Nowacki and Abrams 2008); this was the case in the Missouri Ozark Highlands (Batek et al. 1999, Dey and Hartman 2005, Nelson 2005, Stambaugh and Guyette 2006).

During the fire suppression era post-1940, natural regeneration of the once oak-pine dominant stands took place, which led to the current distribution of more closed, secondgrowth oak woodlands and forests. In the eastern United States, areas that had once experienced intermediate disturbance due to low- or moderate-severity fires were no longer subjected to burning (McEwan 2007, Hutchinson et al. 2012). This exclusion of fire led to what has been coined the "mesophication" of several eastern woodlands and forests (Nowacki and Abrams 2008), in which ecosystem succession has shifted towards more understory-tolerant species reaching maturity than in previously oak-dominated systems.

Mesophication refers to the increasing recruitment and dominance of several mesophytic woody species that had been historically suppressed by fire activity and outcompeted by oak and pine species (Abrams 2003, Iverson et al. 2007, Nowacki and 
Abrams 2008). Fires in oak and oak-pine woodlands altered the competitive relationships within oak systems, allowing for less understory-tolerant oak and pine species to take advantage of reduced inter- and intraspecific competition in burnt areas where light was not a limiting factor (Cottam 1949, Anderson 1998, Nowacki and Abrams 2008). With the removal of fire, oak and pine species were generally less competitive on mesic sites, where more understory-tolerant species were outgrowing and outcompeting advance regeneration of oak, hickory, and pine species. The absence of fire resulted in a more complex vertical woodland profile (Dey and Hartman 2005), and increased seedling species richness due to the co-occurrence of both fire-dependent and fire-independent species (Nowacki and Abrams 2008).

Prescribed fire acts as a disturbance mechanism for the secondary successional pathway of many systems. For example, prescribed burning is known to produce a desirable seedbed that stimulates the sprouting of several herbaceous and woody species (Burton et al. 2011). Fires historically prevented several understory-tolerant tree species from becoming competitive as overstory trees in oak-dominated stands, due to the ability of oaks to outcompete after disturbances, especially fire (Lorimer 1984, Abrams 1998, Fei and Steiner 2007, Abrams and Steiner 2013). In the absence of fire, understorytolerant species are more competitively aggressive in mesic areas, and advance regeneration of overstory species may be excluded (Schuster et al. 2008, Abrams and Steiner 2013).

Current research suggests that one of the primary functions of fire in the promotion of oak and pine species was the reduction of indirect competition, via the removal of herbaceous and faster-growing woody species competitors, on oak and pine advance 
regeneration. The physical structure of under- and overstories, such as stocking densities and the openness of the understory and ground layer, are also affected by fire (Ladd 1991, Nigh et al. 1992, Cutter and Guyette 1994). The removal (by fire) of fast-growing, early-successional species increases the availability of light for regeneration of slowergrowing oaks and understory-intolerant pines, especially on mesic sites (Abrams and Steiner 2013). Oak seedlings, in particular, can preferentially allocate growth below ground for several years; without fire, this trait reduces the likelihood of oaks outcompeting faster-growing species. (Abrams 1992, Lorimer et al. 1994, Nowacki and Abrams 2008, Abrams and Steiner 2013). Oak understory-tolerance ranges from species that are somewhat understory-tolerant, such as white oak (Quercus alba L.) (Rogers 1990), chinkapin oak (Quercus muehlenbergii Engelm.) (Sander 1990a), and northern red oak (Quercus rubra L.) (Sander 1990b), to those that are understory-intolerant, such as scarlet oak (Quercus coccinea Münchh.) (Johnson 1990), blackjack oak (Quercus marilandica Münchh.) (Carey 1992), and post oak (Quercus stellata Wangenh.) (Stransky 1990). The relative intolerance of oak seedlings to understory conditions means that small individuals cannot persist for long periods of time when outcompeted by taller vegetation (Abrams 1992). On xeric sites, where more understory-tolerant species must compete for soil nutrients as well as light, oaks and pines are thought to be more competitive (Abrams 1990, Nowacki and Abrams 2008). Oaks and pines have been most persistent on xeric sites in the eastern US, even in the absence of fire (Abrams 1992, Iverson et al. 1997, Iverson et al. 2007). 
Fire Management in the Missouri Ozarks

In the Missouri Ozark Highlands, anthropogenic fire regimes pre-settlement (presumably Native American fires) had a mean return interval of 10 years, from 1680 to 1850 (Guyette et al. 2002). After European settlement, the fire return interval changed dramatically (Guyette et al. 2002, Stambaugh and Guyette 2006, Nowacki and Abrams 2008). From 1850 to 1890, while European Americans began settling the area, the fire return interval decreased to a mean of 3.5 years. Intense logging and clearing of the Ozark hills took place between 1891 and 1940; during this time, the discontinuity of fuels and preponderance of settlements increased the fire return interval to a mean of 5.8 years. Finally, after 1940 and the rise of suppression practices, the mean fire return interval increased to over 20 years (Guyette et al. 2002). Today, prescribed fire is being used to restore and conserve areas in the Ozark Highlands.

Over 323.7 thousand hectares of glades, woodlands, and forests are under public (state and federal) land management in the Current River Hills Ecological Subsection of the Missouri Ozarks (Nigh and Schroeder 2002). Of those 323,749ha, 32,375ha (ten percent) are owned and managed by the National Park Service, as part of the Ozark National Scenic Riverways (ONSR) (Price 2011). Commercial timber harvest is not permitted on ONSR property, unlike private, state, and other federally-owned lands in the area; therefore, the use of prescribed fire is directed toward ecological restoration, rather than economic gain.

Researchers at the ONSR began collecting long-term prescribed fire data in 1999, in order to track changes in vegetation, including tree regeneration, and fuel accumulation 
in dry-mesic (mesic) and xeric woodland natural communities (Klein et al. 1999). Longterm data sets that include multiple prescribed fire events are uncommon, and current research in reflecting the long-term use of periodic prescribed fire is lacking, especially in the Missouri Ozarks. Studies that describe only the use of fire on advance regeneration management are even less common. This study provides a unique vantage on the impacts of prescribed fire alone. For scientists at ONSR and for other land managers who may wish to restore woodlands, but are unable to apply thinning practices, these data provide a more accurate depiction of how the use of prescribed fire is affecting woody species regeneration over time.

The Current River Hills are characterized as an oak and oak-pine dominated system, where historic fire spread was highly variable and influenced by topographical features and the discontinuity of fuels (Batek et al. 1999, Nigh and Schroeder 2002, Dey and Hartman 2005). Fires typically burn most intensely on xeric summits and ridgetops, due to fires burning uphill. Although some research has examined advance regeneration of oak, pine, and associated fire-tolerant species in the region (Dey and Hartman 2005, for example), there has been no long-term comparison study examining the use of prescribed fires on xeric versus mesic sites. Nowacki and Abrams (2008) suggest that the use of fire or other management on mesic sites in the eastern United States is intrinsically important in the perpetuation of oak systems; the assumption is that oaks and pines are more competitive on xeric areas, but need to be managed to persist and outcompete mesophytic species on richer sites. In light of recent oak decline conditions in the Missouri Ozarks, including on xeric sites where oaks are still dominant (Voelker 2004, Shifley et al. 2006, Kabrick et al. 2008, Fan et al. 2011), it is important for land managers 
to understand how to regenerate and recruit woody species that have been exhibiting stress as adults.

The primary objective of this study was to examine the effects of fire management on the seedling density of species on xeric and mesic sites at ONSR. With the use of seedling density data collected over several years and after several repeated prescribed fires at ONSR, this study aimed to address four hypotheses:

1. The hypothesis that oaks, hickories, and pines are successfully regenerating on xeric sites, under a periodic prescribed fire regime.

2. The hypothesis that periodic prescribed fire is promoting oak, hickory, and/or pine seedling growth on mesic woodland sites.

3. The hypothesis that understory-tolerant species are becoming more prevalent in both xeric and mesic woodland areas.

4. The hypothesis that fire-tolerant species' seedlings are being promoted with the use of periodic prescribed fire. 


\section{METHODS}

Study Area

ONSR covers approximately 83,237ha of land, located primarily within Carter and Shannon Counties. In the Current River Hills ecological subsection of the Missouri Ozark Highlands, mean annual precipitation ranges from $109 \mathrm{~cm}$ (in the north) to $122 \mathrm{~cm}$ (to the south), with most rainfall occurring from March-May and in August. Precipitation is relatively evenly distributed throughout the year, with 56 percent received during the six warmer months. Mean minimum temperature in January is $-6.7^{\circ}$ to $-6.1^{\circ} \mathrm{C}$, while mean maximum daily temperature in July ranges from $31.6^{\circ}$ to $32.8^{\circ} \mathrm{C}$ north to south (Nigh and Schroeder 2002).

ONSR overlays three major landtype associations (LTAs): the Current River OakPine Woodlands, Current River Oak Forest Breaks, and the Jacks Fork Oak-Pine Forest Breaks. In combination, these areas have a mean local relief ranging from $45.7 \mathrm{~m}$ to over 154.2m, with soils derived from the cherty, low-nutrient Roubidoux Formation in upper slopes, the Gasconade Formations mid-slopes, and Eminence-Potosi Formation (dolomite) at low elevations. Permanent plots were established predominantly in the OakPine Woodlands, where mean relief ranges from $45.7 \mathrm{~m}$ to $76.2 \mathrm{~m}$ (Nigh and Schroeder 2002).

Historically, shortleaf pine-oak forests and woodlands were widespread in the River Hills, but the area was heavily cut over in the late 1800 s and early 1900 s to provide timber for milling and smelting operations (Keefe 1987, Price 2011). Dendrochronological studies of standing trees and stumps in the Ozark Highlands show 
that fire return intervals varied from about 10 years pre-European settlement (1680 to 1850), 3.5 years during settlement (1851-1890), 5.8 years during intense settlement use for agriculture and grazing from 1891-1940; after 1940, the return interval increased dramatically, to over 20 years (Guyette et al. 2002, Stambaugh et al. 2005). Stand reinitiation after the clearcutting of the late 1800 s and early 1900 s began during a time when the fire interval transitioned from a mean return of 5.8 years to over 20 .

Today, the Current River Hills are dominated by second-growth oak-pine stands. Due to the suppression of fire after the reinitiation of the oak-pine overstory, current stands are more heavily stocked than previously (Nigh and Schroeder 2002). At ONSR, the overstory is comprised primarily of scarlet oak, black oak (Quercus velutina Lam.), and white oak; black hickory (Carya texana Buckley), mockernut hickory (C. tomentosa [Lam.] Nutt.), and pignut hickory (C. glabra [Mill.] Sweet) are also well represented. Although less common than before the area was logged, dominant shortleaf pine (Pinus echinata Mill.) individuals are dispersed throughout ONSR. The understory is comprised mostly of flowering dogwood (Cornus florida L.) and downy serviceberry (Amelanchier arborea [Michx. f.] Fernald). There is not a strong presence of any oak species in the understory, in either mesic or xeric woodland settings.

Logging has not occurred on original ONSR property since the Park was officially created in 1972, making prescribed fire the first management tool used by ONSR staff on the woodland areas within the boundaries of the Park. Timber harvest is not conducted or funded on most National Park lands, which largely precludes the use of mechanical thinning to manage large areas at ONSR; this makes prescribed fire the most practical tool available for managing the oak woodlands in the area. 


\section{Experimental Design}

Permanent fire effects monitoring plots were established in prescribed fire (burn) units from 1999 to 2007; 14 plots were installed in dry-mesic (mesic) woodlands, 19 in dry (xeric) woodlands, in areas that likely experienced historical natural and anthropogenic fires. Mesic woodland plots were installed in areas in which oak and hickory species were dominant in the $21-30 \mathrm{~m}$ tall overstory, as well as black gum (Nyssa sylvatica Marshall), sugar maple (Acer saccharum Marshall), white ash (Fraxinus americana L.) with canopy cover ranging from 60-100 percent. These plots were installed predominantly on northern and eastern aspects, on saddles, shoulders, backslopes, or benches with well-drained chert, dolomite, or sandstone soils. Mesic woodland plots also had well-developed, 4-7m tall midstories, dominated by flowering dogwood (Cornus florida L.); herbaceous ground cover cover was abundant, ranging from 20-80 percent. These woodlands are not true mesic areas, as the low areas near the rivers at ONSR did not burn frequently and were, therefore, excluded from the sampling design.

Xeric woodland plots were dominated by oaks, hickories, and shortleaf pine in the overstory, with less canopy cover the mesic woodland plots (60 to 90 percent) and a shorter crown height $(15-23 \mathrm{~m})$. These plots were primarily installed on western and southern aspects, mostly on exposed upper slopes and summits, over Roubidoux sandstone or Upper Gasconade dolomite. Xeric woodland plots had sparse understory development, ranging from only 1.5-4.5m height and comprised of flowering dogwood and downy serviceberry. The herbaceous ground layer was sparse, with less than 20 percent cover. Pre-treatment, each mesic and xeric woodland plot was similar structurally 
and in terms of species composition to others in the same natural community.

Due to the distribution of these natural communities across ONSR, the experimental design is unbalanced; fewer mesic woodland areas are sampled than xeric woodlands. Plots are disproportionately distributed throughout burn units; although at least one plot of each natural community type is represented in each unit, some burn units have more than one plot of one natural community, but not the other (for example, one xeric woodland plot and three mesic woodland plots). Prescribed fires were conducted exclusively during the spring dormant season (January to mid-April). Fires were lit primarily by ignitions lining the perimeter of each burn unit, and were of low- to moderate-intensity. High levels of heterogeneity caused fires to burn patchily, due to the varying microclimatic and topographic characteristics at ONSR. Each burn unit was subjected to a varying rotation and frequency of fire use, with the return interval for prescribed fire averaging 4 years for each burn unit. Each plot was subjected to up to four prescribed burns (with a minimum of one burn) by the beginning of this study. No unburned control plots were available for comparison to burn plots; therefore, all plots are compared to each other over time, instead of to a control.

\section{Field Data Collection}

Fire effects plot sampling took place pre-burn, then the first and second growing seasons (May to September) after each prescribed burn. Plots were revisited during the same two-week time span each sampling year, to account for differences that may have been caused by phenological variations in the growth and senescence of plant species. 
Sampling was conducted by re-establishing the boundaries of permanent plots with the use of meter tapes; plot corners were marked with rebar upon installation, and tagged to ensure that sampling efforts within each plot were consistent over time.

Mesic and xeric woodland plots measured 50mx20m; seedling density - advance regeneration - was sampled in permanent $5 \mathrm{mx} 10 \mathrm{~m}(0.005 \mathrm{ha})$ subplots within the larger fire effects plots. Seedlings were defined as individuals less than $2.0 \mathrm{~m}$ height and $2.5 \mathrm{~cm}$ diameter at breast height ( $\mathrm{dbh})$, or $1.37 \mathrm{~m}$ above ground. All seedling individuals in each subplot were counted.

\section{Hypotheses and Data Analysis}

Mean seedling densities per hectare were compared between natural communities, as were mean seedling densities per hectare of understory- and fire-tolerant, intermediately tolerant, and intolerant species, with increasing numbers of burns (levels of a repeated treatment). Species were grouped as to understory and fire tolerance based on the life history descriptions available from the U.S. Forest Service's Fire Effects Information System (FEIS) database (USDA Forest Service 2014; see Table A1, Appendix for list of authors by species). As all seedlings are susceptible to top-kill due to fire, seedling fire tolerance was based on the ability of the root crown to resprout. Fireintolerant species were those that typically do not resprout after being top-killed, and recolonize an area through the seed bank or seed dispersal from surviving adults. Intermediate species are those that are capable of resprouting after low-intensity fires, but not prolifically. Fire-tolerant species are those that are probably top-killed, but resprout 
prolifically from the root crown after most fires. Fire tolerance groupings were based on the plant-fire relationships defined by Rowe (1983) and Agee (1996) in combination with the descriptions provided by the FEIS database. Understory tolerances were examined separately from fire tolerance.

Specific hypotheses tested were:

Null hypothesis: the prescribed fire regime at ONSR has had no noticeable impact on seedling density for oak, hickory, or pine species on xeric sites. Alternative hypothesis: oak, hickory, and/or pine species seedling density seems to increase or decrease due to the prescribed fire regime.

Null hypothesis: the prescribed fire regime at ONSR has had no noticeable impact on seedling density for oak, hickory, or pine species on mesic sites. Alternative hypothesis: oak, hickory, and/or pine species seedling density seems to increase or decrease due to the prescribed fire regime in mesic woodlands.

Null hypothesis: there is no change in seedling density of understory-tolerant species, after repeated prescribed fires. Alternative hypothesis: seedling density of understorytolerant species is increasing or decreasing, after repeated prescribed fires.

Null hypothesis: there is no change in seedling density of fire-tolerant species after repeated prescribed fires. Alternative hypothesis: seedling density of fire-tolerant species has increased or decreased after repeated prescribed fires.

Generalized linear mixed models were used to determine statistically significant differences in the densities of seedlings in mesic and xeric woodlands, with increasing 
numbers of prescribed burns (SAS 9.2, PROC GLIMMIX; SAS Institute Inc., Cary, N.C.). A gamma distribution was fitted to the data, which were not normally distributed. For some data, a non-parametric rank distribution model was applied before comparing means (after Conover and Iman 1981). Natural community type, a random variable, was nested in burn unit, and the number of burns represented the repeated time measure, with burn unit being the repeatedly measured subject (after Hutchinson et al. 2012). An $\mathrm{SP}(\mathrm{POW})$ power-based spatial covariance structure was used to for the repeated time variable, to account for unequal time spacing between sampling events. Least squares (LS) means comparisons for each variable were adjusted using the Tukey-Kramer method for multiple pairwise t-tests. Data means and standard errors were calculated using the ILINK feature in the LSMEANS statement within PROC GLIMMIX (SAS 9.2). 


\section{RESULTS}

A total of 30 tree species were used to compare the means in xeric and mesic woodlands. Of these, 12 were understory-tolerant (40 percent), 10 were intermediately tolerant (33.33 percent), and 8 were understory-intolerant (26.67 percent). Six species were fire-intolerant (20.69 percent), 13 were of intermediate tolerance (44.83 percent), and 11 were fire-tolerant (Table 1).

The use of the Tukey-Kramer method to adjust pairwise population mean comparisons gave the t-tests greater power (type II error is reduced), but resulted in the loss of several significant comparisons after the adjustment. The method is conservative, but appropriate for conducting several comparisons; for this reason, adjusted P-values (AdjP) calculated using the Tukey-Kramer method will be presented. For all tests, the significance level was $\alpha=0.05$. Mean seedling density per hectare varied as to natural community, understory and fire tolerance, and through time (Table 2). 
Table 1. Common names and understory and fire tolerance ratings for 30 sampled tree species at the Ozark National Scenic Riverways. Understory and fire tolerances of seedlings belonging to each species were based on information provided by several authors associated with the US Forest Service Fire Effects Information System Database (www.feis-crs.org/beta/).

\begin{tabular}{|c|c|c|c|}
\hline Species & Common Name & $\begin{array}{c}\text { Understory } \\
\text { Tolerance } \\
\end{array}$ & Fire Tolerance \\
\hline Acer negundo & Box Elder & Intermediate & Intolerant \\
\hline Acer rubrum & Red Maple & Tolerant & Intolerant \\
\hline Acer saccharum & Sugar Maple & Tolerant & Intolerant \\
\hline Amelanchier arborea & Downy Serviceberry & Tolerant & Intolerant \\
\hline Carya glabra & Pignut Hickory & Intermediate & Tolerant \\
\hline Carya ovata & Shagbark Hickory & Intermediate & Intermediate \\
\hline Carya texana & Black Hickory & Intermediate & Tolerant \\
\hline Carya tomentosa & Mockernut Hickory & Intermediate & Intermediate \\
\hline Cornus florida & Flowering Dogwood & Tolerant & Tolerant \\
\hline Fraxinus americana & White Ash & Tolerant & Intermediate \\
\hline Fraxinus pennsylvanica & Green Ash & Intermediate & Intermediate \\
\hline Fraxinus quadrangulata & Blue Ash & Intermediate & Intermediate \\
\hline Juglans nigra & Black Walnut & Intolerant & Intermediate \\
\hline Juniperus virginiana & Eastern Redcedar & Intolerant & Intolerant \\
\hline Nyssa sylvatica & Black Gum & Tolerant & Tolerant \\
\hline Ostrya virginiana & Hophornbeam & Tolerant & Intermediate \\
\hline Pinus echinata & Shortleaf Pine & Intolerant & Tolerant \\
\hline Prunus serotina & Black Cherry & Intolerant & Intermediate \\
\hline Quercus alba & White Oak & Intermediate & Tolerant \\
\hline Quercus coccinea & Scarlet Oak & Intolerant & Intermediate \\
\hline Quercus marilandica & Blackjack Oak & Intolerant & Tolerant \\
\hline Quercus muehlenbergii & Chinkapin Oak & Intermediate & Tolerant \\
\hline Quercus rubra & Northern Red Oak & Intermediate & Intermediate \\
\hline Quercus shumardii & Shumard Oak & Intolerant & Intermediate \\
\hline Quercus stellata & Post Oak & Intolerant & Tolerant \\
\hline Quercus velutina & Black Oak & Intermediate & Tolerant \\
\hline Sassafras albidum & Sassafras & Intolerant & Tolerant \\
\hline Ulmus alata & Winged Elm & Intolerant & Intermediate \\
\hline Ulmus americana & American Elm & Intermediate & Intolerant \\
\hline Ulmus rubra & Slippery Elm & Tolerant & Intermediate \\
\hline
\end{tabular}


Table 2. Mean seedling (stem) density ha $^{-1}$ and standard error (SE) by tolerance, natural community, and burn treatment.

\begin{tabular}{|c|c|c|c|c|c|c|}
\hline \multirow[b]{2}{*}{$\begin{array}{l}\text { Tolerance } \\
\text { Group }\end{array}$} & \multirow[b]{2}{*}{$\begin{array}{c}\text { Natural } \\
\text { Community }\end{array}$} & \multicolumn{5}{|c|}{ Mean Seedling Density $\mathrm{ha}^{-1}( \pm \mathrm{SE})$} \\
\hline & & $\begin{array}{c}0 \\
\text { (Pre- } \\
\text { Burn) }\end{array}$ & 1 Burn & 2 Burns & 3 Burns & 4 Burns \\
\hline \multirow{2}{*}{$\begin{array}{c}\text { Total Density } \\
\text { (All Tolerance } \\
\text { Groups) }\end{array}$} & Xeric & $\begin{array}{c}756.38 \\
( \pm 56.42)\end{array}$ & $\begin{array}{l}1177.62 \\
( \pm 97.62)\end{array}$ & $\begin{array}{l}1018.97 \\
( \pm 80.86)\end{array}$ & $\begin{array}{c}874.04 \\
( \pm 80.81)\end{array}$ & $\begin{array}{c}1582.64 \\
( \pm 216.04)\end{array}$ \\
\hline & Mesic & $\begin{array}{c}1407.37 \\
( \pm 107.60)\end{array}$ & $\begin{array}{c}2100.12 \\
( \pm 176.40)\end{array}$ & $\begin{array}{c}1872.86 \\
( \pm 173.32)\end{array}$ & $\begin{array}{c}1703.97 \\
( \pm 185.49)\end{array}$ & $\begin{array}{c}1524.40 \\
( \pm 310.03)\end{array}$ \\
\hline \multirow{2}{*}{$\begin{array}{l}\text { Understory } \\
\text { Tolerant }\end{array}$} & Xeric & $\begin{array}{c}632.09 \\
( \pm 38.86)\end{array}$ & $\begin{array}{c}584.41 \\
( \pm 36.31)\end{array}$ & $\begin{array}{c}629.11 \\
( \pm 34.62)\end{array}$ & $\begin{array}{c}596.56 \\
( \pm 53.90)\end{array}$ & $\begin{array}{c}515.09 \\
( \pm 60.61)\end{array}$ \\
\hline & Mesic & $\begin{array}{c}520.56 \\
( \pm 24.15)\end{array}$ & $\begin{array}{c}399.99 \\
( \pm 27.09)\end{array}$ & $\begin{array}{c}410.15 \\
( \pm 31.84)\end{array}$ & $\begin{array}{c}454.58 \\
( \pm 33.99)\end{array}$ & $\begin{array}{c}485.43 \\
( \pm 67.82)\end{array}$ \\
\hline \multirow{2}{*}{$\begin{array}{l}\text { Intermediate } \\
\text { Understory } \\
\text { Tolerance }\end{array}$} & Xeric & $\begin{array}{c}638.02 \\
( \pm 63.18)\end{array}$ & $\begin{array}{c}898.36 \\
( \pm 109.63)\end{array}$ & $\begin{array}{c}756.92 \\
( \pm 76.88)\end{array}$ & $\begin{array}{c}670.74 \\
( \pm 79.76)\end{array}$ & $\begin{array}{c}1295.45 \\
( \pm 223.53)\end{array}$ \\
\hline & Mesic & $\begin{array}{c}1027.43 \\
( \pm 122.98)\end{array}$ & $\begin{array}{c}1349.22 \\
( \pm 175.53)\end{array}$ & $\begin{array}{c}945.20 \\
( \pm 143.22)\end{array}$ & $\begin{array}{c}801.82 \\
( \pm 141.87)\end{array}$ & $\begin{array}{c}1118.03 \\
( \pm 387.41)\end{array}$ \\
\hline \multirow{2}{*}{$\begin{array}{l}\text { Understory } \\
\text { Intolerant }\end{array}$} & Xeric & $\begin{array}{c}638.46 \\
( \pm 68.76)\end{array}$ & $\begin{array}{c}1282.72 \\
( \pm 147.82)\end{array}$ & $\begin{array}{c}1246.28 \\
( \pm 135.53)\end{array}$ & $\begin{array}{c}1076.02 \\
( \pm 138.27)\end{array}$ & $\begin{array}{c}2151.31 \\
( \pm 393.33)\end{array}$ \\
\hline & Mesic & $\begin{array}{c}969.88 \\
( \pm 123.78)\end{array}$ & $\begin{array}{c}2192.27 \\
( \pm 335.05)\end{array}$ & $\begin{array}{c}1252.24 \\
( \pm 237.47)\end{array}$ & $\begin{array}{c}1273.59 \\
( \pm 221.43)\end{array}$ & $\begin{array}{c}1623.99 \\
( \pm 451.98)\end{array}$ \\
\hline \multirow{2}{*}{ Fire Tolerant } & Xeric & $\begin{array}{c}843.09 \\
( \pm 69.41)\end{array}$ & $\begin{array}{c}1367.34 \\
( \pm 125.22)\end{array}$ & $\begin{array}{l}1131.15 \\
( \pm 99.59)\end{array}$ & $\begin{array}{c}884.88 \\
( \pm 88.82)\end{array}$ & $\begin{array}{c}1714.68 \\
( \pm 232.70)\end{array}$ \\
\hline & Mesic & $\begin{array}{c}1335.54 \\
( \pm 130.56)\end{array}$ & $\begin{array}{c}1941.29 \\
( \pm 202.37)\end{array}$ & $\begin{array}{c}1478.15 \\
( \pm 196.71)\end{array}$ & $\begin{array}{c}1243.55 \\
( \pm 164.52)\end{array}$ & $\begin{array}{c}1611.96 \\
( \pm 365.98)\end{array}$ \\
\hline \multirow{2}{*}{$\begin{array}{l}\text { Intermediate } \\
\text { Fire Tolerance }\end{array}$} & Xeric & $\begin{array}{c}460.12 \\
( \pm 95.12)\end{array}$ & $\begin{array}{c}543.62 \\
( \pm 113.19)\end{array}$ & $\begin{array}{c}650.25 \\
( \pm 136.96)\end{array}$ & $\begin{array}{c}494.11 \\
( \pm 120.50)\end{array}$ & $\begin{array}{c}625.56 \\
( \pm 270.43)\end{array}$ \\
\hline & Mesic & $\begin{array}{c}691.66 \\
( \pm 99.86)\end{array}$ & $\begin{array}{c}1041.39 \\
( \pm 165.47)\end{array}$ & $\begin{array}{c}923.97 \\
( \pm 152.07)\end{array}$ & $\begin{array}{c}890.96 \\
( \pm 204.98)\end{array}$ & $\begin{array}{c}516.40 \\
( \pm 210.49)\end{array}$ \\
\hline \multirow{2}{*}{ Fire Intolerant } & Xeric & $\begin{array}{c}192.01 \\
( \pm 28.40)\end{array}$ & $\begin{array}{c}184.90 \\
( \pm 30.49)\end{array}$ & $\begin{array}{c}199.54 \\
( \pm 38.13)\end{array}$ & $\begin{array}{c}178.81 \\
( \pm 82.57)\end{array}$ & $\begin{array}{c}214.57 \\
( \pm 82.52)\end{array}$ \\
\hline & Mesic & $\begin{array}{c}137.75 \\
( \pm 13.79)\end{array}$ & $\begin{array}{c}113.88 \\
( \pm 12.03)\end{array}$ & $\begin{array}{c}124.05 \\
( \pm 15.04)\end{array}$ & $\begin{array}{c}102.89 \\
( \pm 13.94)\end{array}$ & $\begin{array}{c}146.09 \\
( \pm 35.92)\end{array}$ \\
\hline
\end{tabular}


Seedling density was significantly greater in mesic woodlands than in xeric woodlands pre-burn and after 1,2, and 3 burns. There was no difference in seedling density between xeric and mesic plots after 4 burns (Figure 1, Table 3).

Seedling density increased in xeric woodland plots after 1 burn, compared to preburn density, but did not significantly change from 1 to 2 burns or from 2 to 3 burns. Seedling density increased between 3 and 4 burns. In xeric woodlands, the overall change, from pre-burn density to density after the fourth burn, was highly significant. In mesic woodlands, there was a significant initial increase in seedling density between 0 and 1 burns. Seedling density slowly decreased from the time period following the first burn to after the fourth burns, but none of the changes were significant. Unlike in the xeric woodlands, there was not a significant difference between seedling density pre-burn and after the fourth burn (Table 4). 
Table 3. $t$-values and Tukey-Kramer adjusted P-values for the comparison of seedling density for all species, between xeric and mesic woodlands, with the continued use of fire. For all comparisons, $\alpha=0.05$.

\begin{tabular}{|c|c|c|c|c|c|}
\hline \multirow{2}{*}{$\begin{array}{c}\text { Statistical } \\
\text { Comparisons }\end{array}$} & \multicolumn{5}{|c|}{ Number of Fires } \\
\hline & Pre-Fire & 1 Fire & 2 Fires & 3 Fires & 4 Fires \\
\hline$t$ - values & -5.81 & -4.90 & -4.99 & -4.67 & 0.15 \\
\hline Adjusted $P<|t|$ & 0.0001 & 0.0001 & 0.0001 & 0.0001 & 1.0000 \\
\hline
\end{tabular}

Table 4. $t$-values and Tukey-Kramer adjusted P-values for the comparison of seedling density of all species after repeated fire in xeric and mesic woodlands. For all comparisons, $\alpha=0.05$.

\begin{tabular}{|c|c|c|c|c|c|c|}
\hline \multirow{2}{*}{$\begin{array}{c}\text { Natural } \\
\text { Community }\end{array}$} & \multirow{2}{*}{$\begin{array}{c}\text { Statistical } \\
\text { Comparisons }\end{array}$} & \multicolumn{5}{|c|}{ Number of Fires } \\
\hline & & $\begin{array}{c}\text { Pre- to } \\
\text { After } 1 \\
\text { Fire }\end{array}$ & $\begin{array}{l}1 \text { to } 2 \\
\text { Fires }\end{array}$ & $\begin{array}{l}2 \text { to } 3 \\
\text { Fires }\end{array}$ & $\begin{array}{l}3 \text { to } 4 \\
\text { Fires }\end{array}$ & Overall \\
\hline \multirow{2}{*}{$\begin{array}{c}\text { Xeric } \\
\text { Woodlands }\end{array}$} & $t$ - values & -3.97 & 1.26 & 1.26 & -3.6 & -4.75 \\
\hline & Adjusted $P<|t|$ & 0.003 & 0.962 & 0.9623 & 0.0120 & $<0.0001$ \\
\hline \multirow{2}{*}{$\begin{array}{c}\text { Mesic } \\
\text { Woodlands }\end{array}$} & $t$ - values & -3.52 & 0.92 & 0.66 & 0.48 & -0.37 \\
\hline & Adjusted $P<|t|$ & 0.0157 & 0.9960 & 0.9997 & 1.0000 & 1.0000 \\
\hline
\end{tabular}




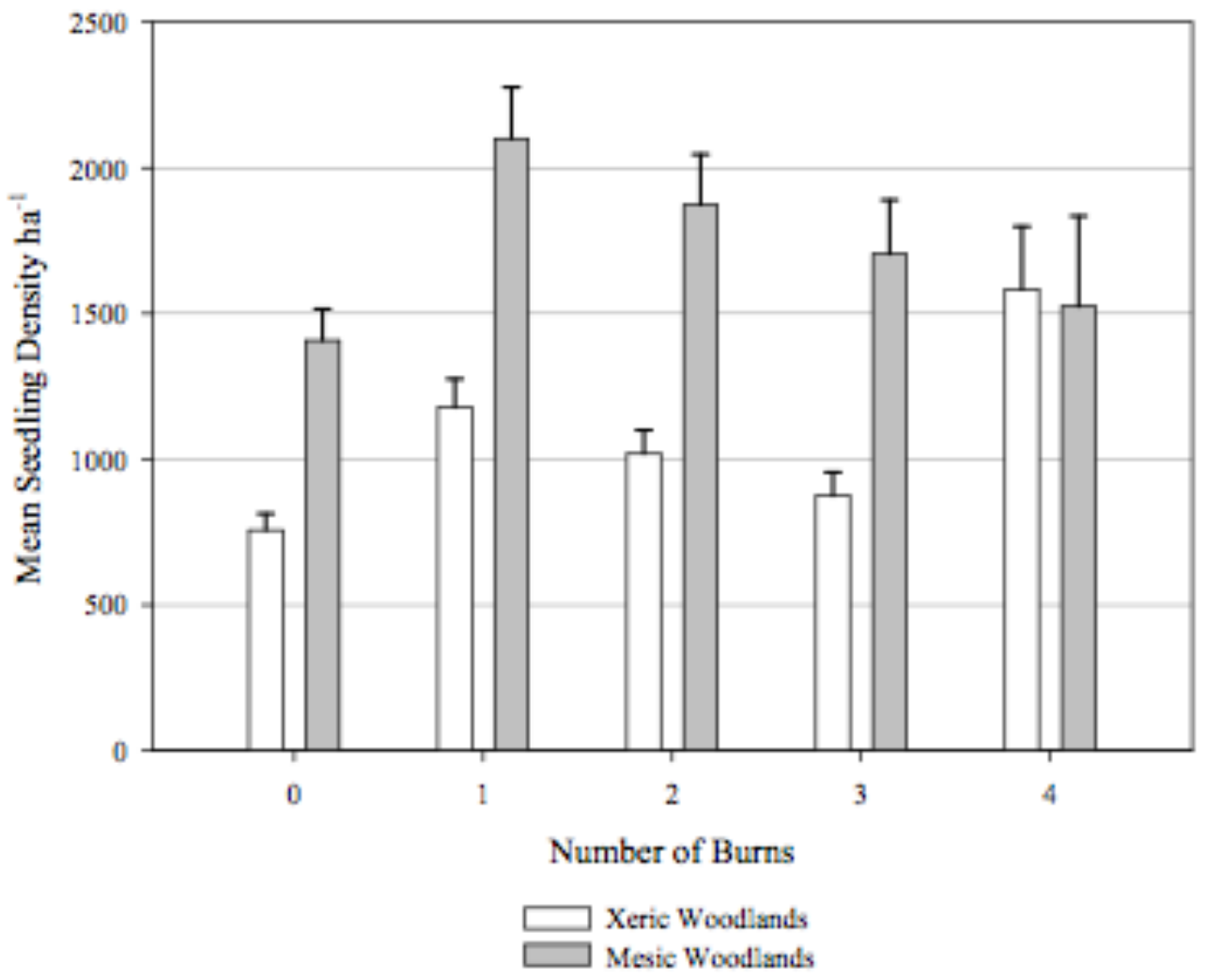

Figure 1. Mean seedling density ha- ${ }^{-1}$ per burn treatment in xeric and mesic woodlands at the Ozark National Scenic Riverways. 


\section{Oak, Hickory, and Pine Species}

Four hickory species were found consistently at ONSR: bitternut hickory $(C$. cordiformis), pignut hickory (Carya glabra), black hickory (C. texana), and mockernut hickory (C. tomentosa). Although shagbark hickory (C. ovata) was found at ONSR, it was found only once; therefore, shagbark hickory was excluded from the consideration of dominant hickory species at ONSR.

Bitternut hickory seedling density was not significantly different between natural communities (Table 5), nor did the density change after burn treatments in xeric or mesic woodlands. In xeric woodlands, the overall change in seedling density from pre-burn to after the third burn was not significant; this was also true in mesic woodlands (Figure 2a, Table 6).

There were no differences in seedling density between natural communities for pignut hickory (Table 5), or response to treatment in xeric or mesic woodlands. Overall seedling density change of pignut hickory, from pre-burn to after the fourth burn, was not significant in xeric or mesic woodlands (Figure 2b) (Table 6).

Pre-burn, black hickory seedling density was higher in mesic plots than in xeric plots, but there were no other differences between communities (Table 5). In xeric woodlands, black hickory seedling density significantly increased pre-burn to after the fourth burn, but not between other treatments. In mesic woodlands, there was a significant decline in black hickory seedling density from pre-burn to after the fourth, but, again, no significant differences between each consecutive treatment (Figure 2c) (Table 6). 
Mockernut hickory seedling density was greater in mesic woodlands after a single burn, but density between natural communities was not significantly different for any other treatment; no seedlings were found in mesic woodlands after the fourth burn (Table 5). No significant differences were found in xeric woodlands, including overall. In mesic woodlands, mockernut hickory seedling density increased significantly pre-burn to after the first burn, decreased from the first to second, and did not change between the second and third burns. Overall, pre-burn density and that after the third burn were not significant (Figure 2d) (Table 6). 
Table 5. $t$-values and Tukey-Kramer adjusted P-values for the comparison of seedling density for hickory species, between xeric and mesic woodlands, with the continued use of fire. For all comparisons, $\alpha=0.05$.

\begin{tabular}{|c|c|c|c|c|c|c|}
\hline \multirow{2}{*}{ Species } & \multirow{2}{*}{$\begin{array}{c}\text { Statistical } \\
\text { Comparisons }\end{array}$} & \multicolumn{5}{|c|}{ Number of Fires } \\
\hline & & Pre-Fire & 1 Fire & 2 Fires & 3 Fires & 4 Fires \\
\hline \multirow{2}{*}{$\begin{array}{l}\text { Bitternut } \\
\text { Hickory }\end{array}$} & $t$ - values & 0.60 & - & - & 0.70 & - \\
\hline & Adjusted $P<|t|$ & 0.9730 & - & - & 0.9545 & - \\
\hline \multirow{2}{*}{$\begin{array}{l}\text { Pignut } \\
\text { Hickory }\end{array}$} & $t$ - values & 0.26 & -1.49 & -1.11 & 2.21 & -0.36 \\
\hline & Adjusted $P<|t|$ & 1.0000 & 0.9528 & 0.9958 & 0.5899 & 1.0000 \\
\hline \multirow{2}{*}{$\begin{array}{c}\text { Black } \\
\text { Hickory }\end{array}$} & $t$ - values & -5.96 & -0.80 & 2.30 & 2.14 & 1.35 \\
\hline & Adjusted $P<|t|$ & $<0.0001$ & 0.9999 & 0.5572 & 0.6712 & 0.9854 \\
\hline \multirow{2}{*}{$\begin{array}{l}\text { Mockernut } \\
\text { Hickory }\end{array}$} & $t$ - values & -1.78 & -5.42 & 0.56 & 0.38 & - \\
\hline & Adjusted $P<|t|$ & 0.6939 & $<0.0001$ & 0.9997 & 1.0000 & - \\
\hline
\end{tabular}


Table 6. $t$-values and Tukey-Kramer adjusted P-values for the comparison of seedling density of each hickory species after repeated fire in xeric and mesic woodlands. For all comparisons, $\alpha=0.05$.

\begin{tabular}{|c|c|c|c|c|c|c|c|}
\hline \multirow{2}{*}{ Species } & \multirow{2}{*}{$\begin{array}{c}\text { Natural } \\
\text { Community }\end{array}$} & \multirow{2}{*}{$\begin{array}{c}\text { Statistical } \\
\text { Comparisons }\end{array}$} & \multicolumn{5}{|c|}{ Number of Fires } \\
\hline & & & $\begin{array}{c}\text { Pre-Fire } \\
\text { to After } \\
1 \text { Fire } \\
\end{array}$ & $\begin{array}{l}1 \text { to } 2 \\
\text { Fires }\end{array}$ & $\begin{array}{l}2 \text { to } 3 \\
\text { Fires }\end{array}$ & $\begin{array}{l}3 \text { to } 4 \\
\text { Fires }\end{array}$ & Overall \\
\hline \multirow{4}{*}{$\begin{array}{l}\text { Bitternut } \\
\text { Hickory }\end{array}$} & \multirow{2}{*}{$\begin{array}{c}\text { Xeric } \\
\text { Woodlands }\end{array}$} & $t$ - values & - & - & 0.50 & - & 0.50 \\
\hline & & $\begin{array}{c}\text { Adjusted } P< \\
|t|\end{array}$ & - & - & 0.9863 & - & 0.9863 \\
\hline & \multirow{2}{*}{$\begin{array}{c}\text { Mesic } \\
\text { Woodlands }\end{array}$} & $t$ - values & -0.60 & - & - & - & 0.60 \\
\hline & & $\begin{array}{c}\text { Adjusted } P< \\
|t|\end{array}$ & 0.9730 & - & - & - & 0.9730 \\
\hline \multirow{4}{*}{$\begin{array}{l}\text { Pignut } \\
\text { Hickory }\end{array}$} & \multirow{2}{*}{$\begin{array}{c}\text { Xeric } \\
\text { Woodlands }\end{array}$} & $t$ - values & -0.23 & -0.89 & -1.31 & -1.29 & -3.38 \\
\hline & & $\begin{array}{c}\text { Adjusted } P< \\
|t|\end{array}$ & 1.0000 & 0.9995 & 0.9820 & 0.9908 & 0.0590 \\
\hline & \multirow{2}{*}{$\begin{array}{c}\text { Mesic } \\
\text { Woodlands }\end{array}$} & $t$ - values & -1.88 & -0.20 & 1.92 & -2.43 & -2.62 \\
\hline & & $\begin{array}{c}\text { Adjusted } P< \\
|t|\end{array}$ & 0.7979 & 1.0000 & 0.7780 & 0.4360 & 0.3173 \\
\hline \multirow{4}{*}{$\begin{array}{c}\text { Black } \\
\text { Hickory }\end{array}$} & \multirow{2}{*}{$\begin{array}{c}\text { Xeric } \\
\text { Woodlands }\end{array}$} & $t$ - values & -4.01 & -0.42 & 0.45 & -1.59 & -3.13 \\
\hline & & $\begin{array}{c}\text { Adjusted } P< \\
|t|\end{array}$ & 0.0082 & 1.0000 & 1.0000 & 0.9460 & 0.1149 \\
\hline & \multirow{2}{*}{$\begin{array}{c}\text { Mesic } \\
\text { Woodlands }\end{array}$} & $t$ - values & 2.68 & 2.03 & 0.16 & -1.46 & 3.68 \\
\hline & & $\begin{array}{c}\text { Adjusted } P< \\
|t|\end{array}$ & 0.3075 & 0.7450 & 1.0000 & 0.9714 & 0.0244 \\
\hline \multirow{4}{*}{$\begin{array}{l}\text { Mockernut } \\
\text { Hickory }\end{array}$} & \multirow{2}{*}{$\begin{array}{c}\text { Xeric } \\
\text { Woodlands }\end{array}$} & $t$ - values & -1.61 & -1.49 & 1.67 & -1.04 & -2.07 \\
\hline & & $\begin{array}{c}\text { Adjusted } P< \\
|t|\end{array}$ & 0.7945 & 0.8525 & 0.7629 & 0.9798 & 0.5075 \\
\hline & \multirow{2}{*}{$\begin{array}{c}\text { Mesic } \\
\text { Woodlands }\end{array}$} & $t$ - values & -5.55 & 4.61 & 1.70 & - & - \\
\hline & & $\begin{array}{c}\text { Adjusted } P< \\
|t|\end{array}$ & $<0.0001$ & 0.0012 & 0.7441 & - & - \\
\hline
\end{tabular}



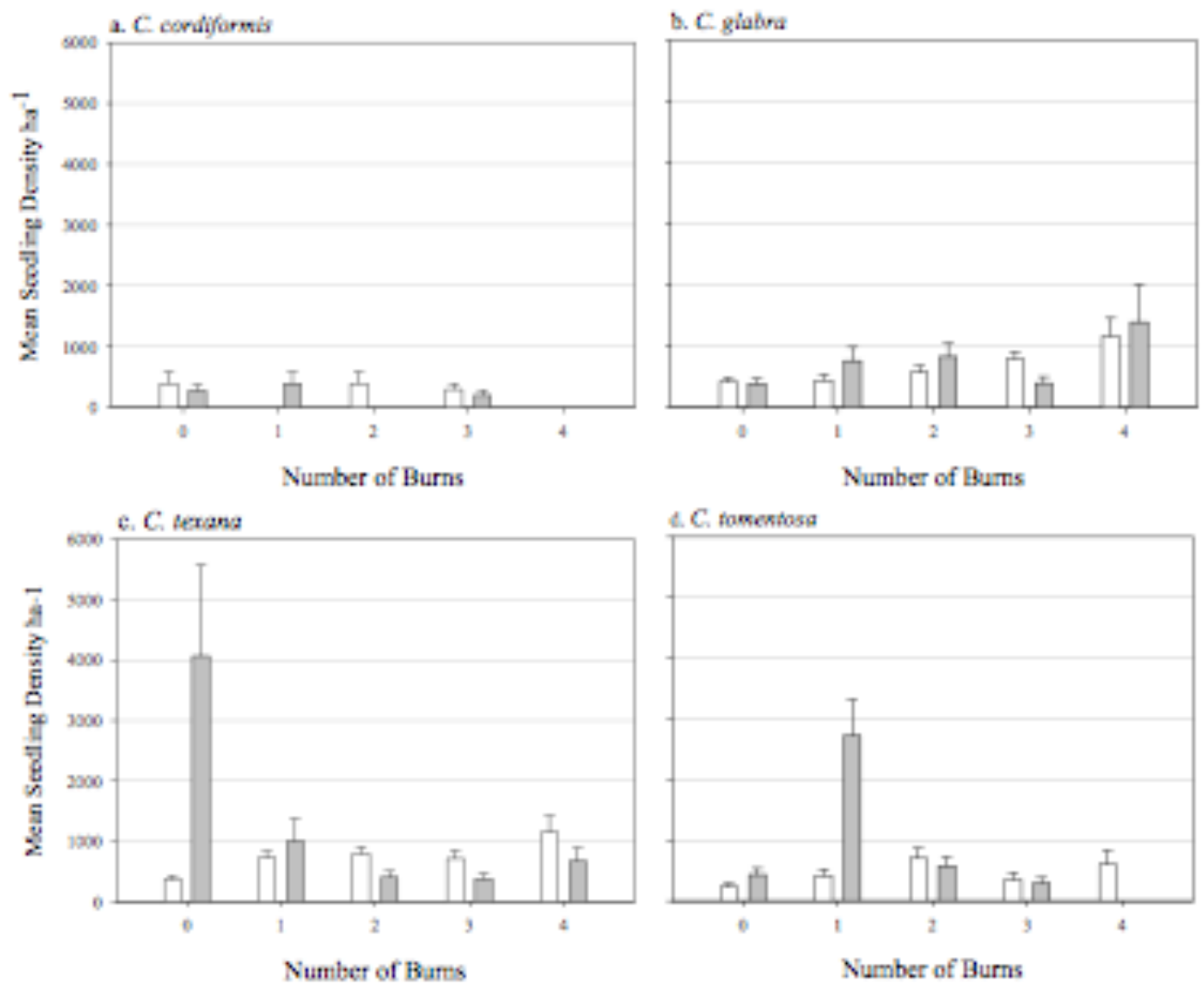

$\square$ Xeric Woodlands
$\square$ Mesic Woodlands

Figure 2. Mean seedling density ha-1 in xeric and mesic woodlands of a.) bitternut hickory, b.) pignut hickory, c.) black hickory, and d.) mockernut hickory at ONSR. 
Shortleaf pine seedling density was not significantly different between natural communities, for any burn treatment (Table 7); no seedlings were found in mesic woodland plots, after a single or four burns. There were no differences between repeated treatments in xeric or mesic woodlands, including overall density (Figure 3) (Table 8). 
Table 7. $t$-values and Tukey-Kramer adjusted P-values for the comparison of seedling density for shortleaf pine, between xeric and mesic woodlands, with the continued use of fire. For all comparisons, $\alpha=0.05$.

\begin{tabular}{|c|c|c|c|c|c|}
\hline \multirow{2}{*}{$\begin{array}{c}\text { Statistical } \\
\text { Comparisons }\end{array}$} & \multicolumn{5}{|c|}{ Number of Fires } \\
\hline & Pre-Fire & 1 Fire & 2 Fires & 3 Fires & 4 Fires \\
\hline$t$ - values & 0.39 & - & 1.70 & -1.13 & - \\
\hline Adjusted $P<|t|$ & 1.0000 & - & 0.7766 & 0.9702 & - \\
\hline
\end{tabular}

Table 8. $t$-values and Tukey-Kramer adjusted P-values for the comparison of seedling density of shortleaf pine after repeated fire in xeric and mesic woodlands. For all comparisons, $\alpha=0.05$.

\begin{tabular}{|c|c|c|c|c|c|c|}
\hline \multirow{2}{*}{$\begin{array}{c}\text { Natural } \\
\text { Community }\end{array}$} & \multirow{2}{*}{$\begin{array}{c}\text { Statistical } \\
\text { Comparisons }\end{array}$} & \multicolumn{5}{|c|}{ Number of Fires } \\
\hline & & $\begin{array}{l}\text { Pre-Fire } \\
\text { to After } \\
1 \text { Fire }\end{array}$ & $\begin{array}{l}1 \text { to } 2 \\
\text { Fires }\end{array}$ & $\begin{array}{l}2 \text { to } 3 \\
\text { Fires }\end{array}$ & $\begin{array}{l}3 \text { to } 4 \\
\text { Fires }\end{array}$ & Overall \\
\hline \multirow[t]{2}{*}{$\begin{array}{c}\text { Xeric } \\
\text { Woodlands }\end{array}$} & $t$ - values & -0.50 & -1.80 & 1.66 & -1.23 & -2.02 \\
\hline & Adjusted $P<|t|$ & 0.9999 & 0.7278 & 0.797 & 0.9517 & 0.6025 \\
\hline \multirow[t]{2}{*}{$\begin{array}{c}\text { Mesic } \\
\text { Woodlands }\end{array}$} & $t$ - values & -0.52 & - & -1.26 & - & -1.15 \\
\hline & Adjusted $P<|t|$ & 0.9999 & - & 0.9467 & - & 0.8539 \\
\hline
\end{tabular}

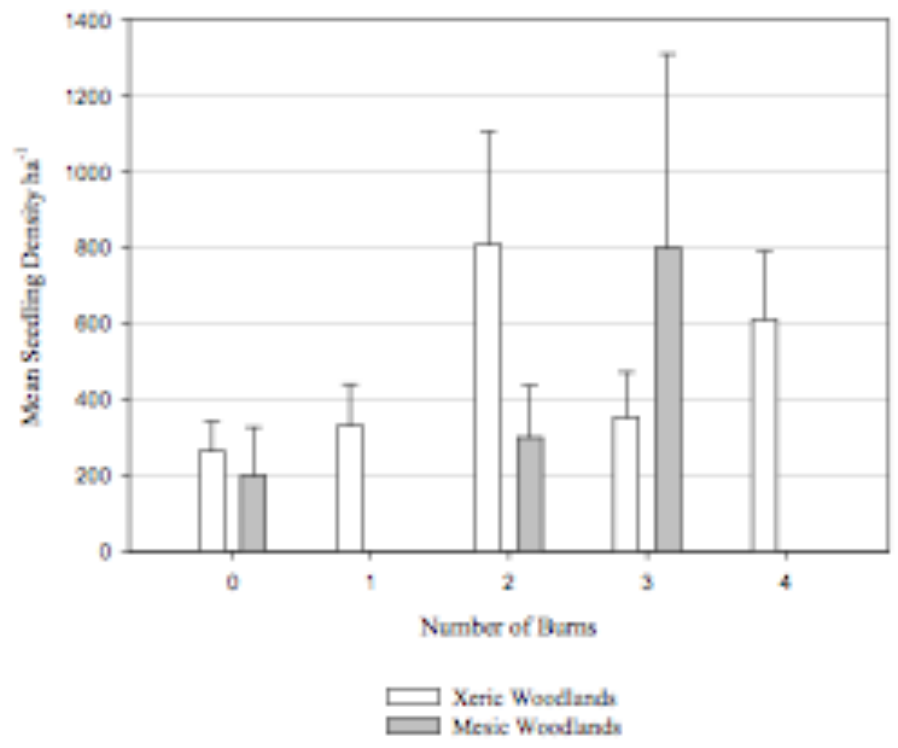

Figure 3. Mean seedling density ha ${ }^{-1}$ of shortleaf pine in xeric and mesic woodlands at ONSR. 
Seven oak species were sampled at ONSR: three were in the white oak group (leucobalanus) - white, chinkapin, and post oak - and five in the red oak group (erythrobalanus) - scarlet, blackjack, northern red, and black oak. Blackjack oak seedlings were only sampled in four xeric woodland plots, in four different burn units, after three different treatments. For this reason, a comparison of means between natural communities or after repeated burns was not possible. The number of seedlings sampled in each plot ranged from 200-400ha- . $^{-1}$

White oak seedling density was not significantly different between natural communities for any treatment (Table 9), nor did density change after repeated treatments in xeric or mesic woodlands. There was not an overall increase in seedling density from pre-burn to after the fourth burn in xeric or mesic woodlands (Figure 4a) (Table 10).

Chinkapin oak seedling density was only comparable pre-burn and after the third burn, as seedlings were not found in xeric woodlands after any other treatment; the comparisons were not significantly different (Table 9). There was no difference in chinkapin oak seedling density pre-burn to after the third in xeric woodlands. There were no treatment differences in mesic woodlands. The overall difference in seedling density in mesic woodlands pre-burn to after the third burn was not significant (Figure 4b) (Table $10)$.

For post oaks, seedlings were only found in mesic woodlands after a single burn; seedling density was not significantly different between the xeric and mesic plots for that treatment (Table 9). There were no repeated treatment differences in seedling density or an overall significant difference pre-burn to after the fourth in xeric woodlands (Figure 
4c) (Table 10).

There were no natural community differences of the seedling density for scarlet oak (Table 9), or differences in seedling densities after repeated burn treatments in xeric or mesic woodlands. Overall, there was no significant difference in scarlet oak seedling density pre-burn to after the fourth burn, in xeric or mesic woodlands (Figure 5a) (Table 11).

No differences were found in the density of northern red oak seedlings between xeric and mesic woodlands (Table 9); no seedlings were found in mesic woodlands after four burns. No significant changes in northern red oak seedling density were found after increasing burns in xeric or mesic woodlands, from fire to fire or overall (Figure 5b) (Table 11).

Black oak seedling density was greater in xeric woodlands than in mesic woodlands after one burn, but no other differences between natural communities were found (Table 9). There were no differences in black oak seedling density after repeated burns in xeric or mesic woodlands. Overall, there was no significant difference in black oak seedling density pre-burn to after the fourth burn in either natural community (Figure 5c) (Table $11)$. 
Table 9. $t$-values and Tukey-Kramer adjusted P-values for the comparison of seedling density for oak species, between xeric and mesic woodlands, with the continued use of fire. For all comparisons, $\alpha=0.05$.

\begin{tabular}{|c|c|c|c|c|c|c|}
\hline \multirow{2}{*}{ Species } & \multirow{2}{*}{$\begin{array}{c}\text { Statistical } \\
\text { Comparisons }\end{array}$} & \multicolumn{5}{|c|}{ Number of Fires } \\
\hline & & $\begin{array}{l}\text { Pre- } \\
\text { Fire }\end{array}$ & 1 Fire & 2 Fires & 3 Fires & 4 Fires \\
\hline \multirow{2}{*}{$\begin{array}{l}\text { White } \\
\text { Oak }\end{array}$} & $t$ - values & 0.31 & 0.35 & 1.80 & 2.52 & 1.38 \\
\hline & Adjusted $P<|t|$ & 1.0000 & 1.0000 & 0.7779 & 0.3025 & 0.9521 \\
\hline \multirow{2}{*}{$\begin{array}{c}\text { Chinkapin } \\
\text { Oak }\end{array}$} & $t$ - values & -1.55 & - & - & -1.25 & 一 \\
\hline & Adjusted $P<|t|$ & 0.8641 & - & - & 0.9604 & - \\
\hline \multirow{2}{*}{ Post Oak } & $t$ - values & - & -1.14 & - & - & - \\
\hline & Adjusted $\mathrm{P}<|\boldsymbol{t}|$ & 一 & 0.9860 & - & - & - \\
\hline \multirow{2}{*}{$\begin{array}{c}\text { Scarlet } \\
\text { Oak }\end{array}$} & $t$ - values & -0.98 & 1.04 & 0.74 & -1.81 & -1.3 \\
\hline & Adjusted $P<|t|$ & 0.9985 & 0.9975 & 0.9999 & 0.8377 & 0.9831 \\
\hline \multirow{2}{*}{$\begin{array}{l}\text { Northern } \\
\text { Red Oak }\end{array}$} & $t$ - values & 0.85 & -0.55 & 0.12 & 0.38 & - \\
\hline & Adjusted $P<|t|$ & 0.997 & 0.9999 & 1.0000 & 1.0000 & - \\
\hline \multirow{2}{*}{ Black Oak } & $t$ - values & 1.92 & 3.37 & 0.00 & 2.08 & 0.84 \\
\hline & Adjusted $P<|t|$ & 0.7739 & 0.0495 & 1.0000 & 0.6785 & 0.9998 \\
\hline
\end{tabular}


Table 10. $t$-values and Tukey-Kramer adjusted P-values for the comparison of seedling density of white oak group species after repeated fire in xeric and mesic woodlands. For all comparisons, $\alpha=0.05$.

\begin{tabular}{|c|c|c|c|c|c|c|c|}
\hline \multirow[b]{2}{*}{ Species } & \multirow[b]{2}{*}{$\begin{array}{c}\text { Natural } \\
\text { Community }\end{array}$} & \multirow[b]{2}{*}{$\begin{array}{c}\text { Statistical } \\
\text { Comparisons }\end{array}$} & \multicolumn{5}{|c|}{ Number of Fires } \\
\hline & & & $\begin{array}{c}\text { Pre- } \\
\text { Fire to } \\
\text { After } 1 \\
\text { Fire }\end{array}$ & $\begin{array}{l}1 \text { to } 2 \\
\text { Fires }\end{array}$ & $\begin{array}{l}2 \text { to } 3 \\
\text { Fires }\end{array}$ & $\begin{array}{l}3 \text { to } 4 \\
\text { Fires }\end{array}$ & Overall \\
\hline \multirow{4}{*}{ White Oak } & \multirow{2}{*}{$\begin{array}{c}\text { Xeric } \\
\text { Woodlands }\end{array}$} & $t$ - values & 0.93 & -1.25 & 0.02 & -0.11 & -0.26 \\
\hline & & Adjusted $P<|t|$ & 0.9975 & 0.9755 & 1.0000 & 1.0000 & 1.0000 \\
\hline & \multirow{2}{*}{$\begin{array}{c}\text { Mesic } \\
\text { Woodlands }\end{array}$} & $t$ - values & 0.99 & 0.23 & 1.30 & 0.05 & 1.31 \\
\hline & & Adjusted $P<|t|$ & 0.996 & 1.0000 & 0.9679 & 1.0000 & 0.9665 \\
\hline \multirow{4}{*}{$\begin{array}{l}\text { Chinkapin } \\
\text { Oak }\end{array}$} & \multirow{2}{*}{$\begin{array}{c}\text { Xeric } \\
\text { Woodlands }\end{array}$} & $t$ - values & - & - & - & - & 0.00 \\
\hline & & Adjusted $P<|t|$ & - & - & - & - & 1.0000 \\
\hline & \multirow{2}{*}{$\begin{array}{c}\text { Mesic } \\
\text { Woodlands }\end{array}$} & $t$ - values & 0.44 & -1.16 & 0.91 & - & 0.32 \\
\hline & & Adjusted $P<|t|$ & 1.0000 & 0.9749 & 0.9955 & - & 1.0000 \\
\hline \multirow{4}{*}{ Post Oak } & \multirow{2}{*}{$\begin{array}{c}\text { Xeric } \\
\text { Woodlands }\end{array}$} & $t$ - values & 0.60 & 0.20 & -0.59 & 2.07 & 2.19 \\
\hline & & Adjusted $P<|t|$ & 0.9999 & 1.0000 & 1.0000 & 0.6054 & 0.5203 \\
\hline & \multirow{2}{*}{$\begin{array}{c}\text { Mesic } \\
\text { Woodlands }\end{array}$} & $t$ - values & - & - & - & - & - \\
\hline & & Adjusted $P<|t|$ & - & - & - & - & - \\
\hline
\end{tabular}



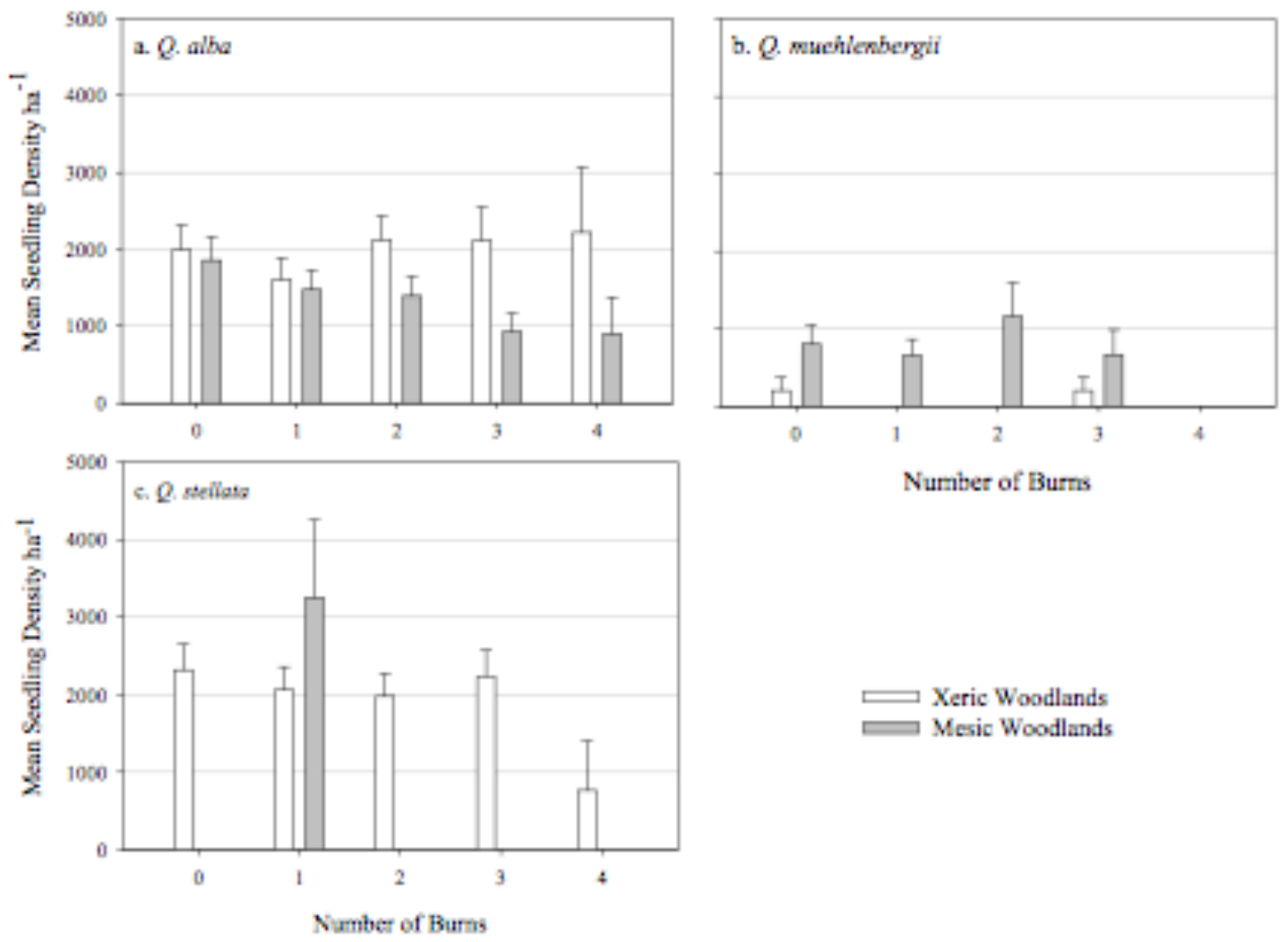

Figure 4. Mean seedling density ha- ${ }^{-1}$, in xeric and mesic woodlands, for a) white oak, b.) chinkapin oak, and c.) post oak (leucobalanus) at ONSR. 
Table 11. $t$-values and Tukey-Kramer adjusted P-values for the comparison of seedling density of red oak group species after repeated fire in xeric and mesic woodlands. For all comparisons, $\alpha=0.05$.

\begin{tabular}{|c|c|c|c|c|c|c|c|}
\hline \multirow[b]{2}{*}{ Species } & \multirow[b]{2}{*}{$\begin{array}{c}\text { Natural } \\
\text { Community }\end{array}$} & \multirow[b]{2}{*}{$\begin{array}{c}\text { Statistical } \\
\text { Comparisons }\end{array}$} & \multicolumn{5}{|c|}{ Number of Fires } \\
\hline & & & $\begin{array}{c}\text { Pre- } \\
\text { Fire to } \\
\text { After } 1 \\
\text { Fire } \\
\end{array}$ & $\begin{array}{l}1 \text { to } 2 \\
\text { Fires }\end{array}$ & $\begin{array}{l}2 \text { to } 3 \\
\text { Fires }\end{array}$ & $\begin{array}{l}3 \text { to } 4 \\
\text { Fires }\end{array}$ & Overall \\
\hline \multirow{4}{*}{$\begin{array}{l}\text { Scarlet } \\
\text { Oak }\end{array}$} & \multirow{2}{*}{$\begin{array}{c}\text { Xeric } \\
\text { Woodlands }\end{array}$} & $t$ - values & -0.42 & 0.04 & 0.16 & 0.16 & 0.06 \\
\hline & & Adjusted $P<|t|$ & 1.0000 & 1.0000 & 1.0000 & 1.0000 & 0.9403 \\
\hline & \multirow{2}{*}{$\begin{array}{c}\text { Mesic } \\
\text { Woodlands }\end{array}$} & $t$ - values & 1.40 & -0.17 & -1.93 & -0.12 & -0.99 \\
\hline & & Adjusted $P<|t|$ & 0.9693 & 1.0000 & 0.769 & 1.0000 & 0.9985 \\
\hline \multirow{4}{*}{$\begin{array}{l}\text { Northern } \\
\text { Red Oak }\end{array}$} & \multirow{2}{*}{$\begin{array}{c}\text { Xeric } \\
\text { Woodlands }\end{array}$} & $t$ - values & -0.02 & -0.59 & 1.49 & -0.62 & -0.06 \\
\hline & & Adjusted $\mathrm{P}<|\boldsymbol{t}|$ & 1.0000 & 0.9998 & 0.8869 & 0.9997 & 1.0000 \\
\hline & \multirow{2}{*}{$\begin{array}{c}\text { Mesic } \\
\text { Woodlands }\end{array}$} & $t$ - values & -1.66 & 0.03 & 1.49 & - & 0.55 \\
\hline & & Adjusted $P<|t|$ & 0.8105 & 1.0000 & 0.8869 & - & 0.9999 \\
\hline \multirow{4}{*}{$\begin{array}{c}\text { Black } \\
\text { Oak }\end{array}$} & \multirow{2}{*}{$\begin{array}{c}\text { Xeric } \\
\text { Woodlands }\end{array}$} & t- values & -1.88 & 3.01 & -0.28 & -1.23 & -0.66 \\
\hline & & Adjusted $P<|t|$ & 0.8069 & 0.1320 & 1.0000 & 0.9904 & 1.0000 \\
\hline & \multirow{2}{*}{$\begin{array}{c}\text { Mesic } \\
\text { Woodlands }\end{array}$} & $t$ - values & 0.07 & -0.89 & 1.73 & -0.94 & -0.31 \\
\hline & & Adjusted $P<|t|$ & 1.0000 & 0.9995 & 0.8778 & 0.9993 & 1.0000 \\
\hline
\end{tabular}



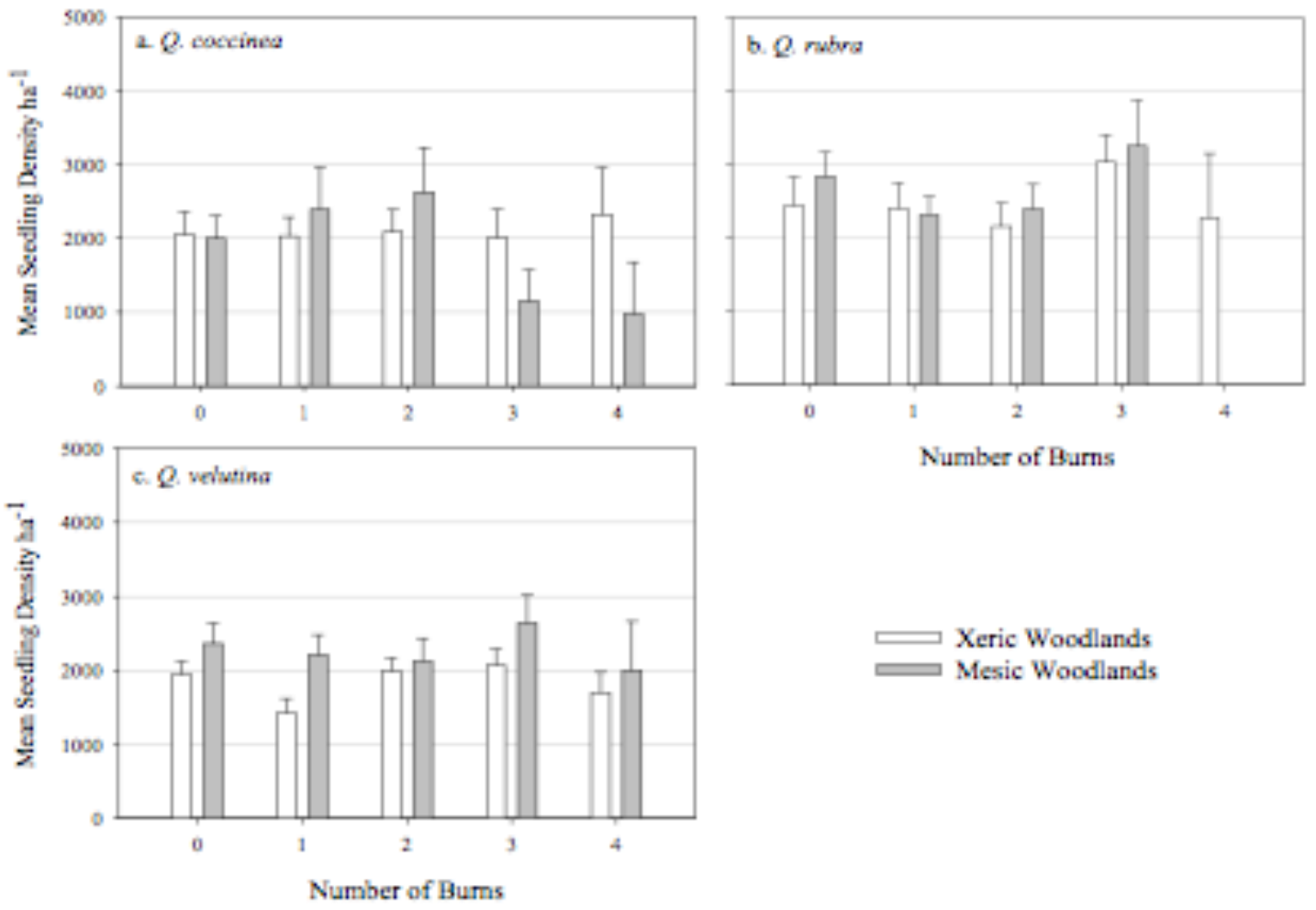

Number of Burns

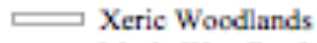

Mesic Woodlands

Figure 5. Mean seedling density ha-1 of a.) scarlet oak, b.) northern red oak, and c.) black oak (erythrobalanus), in xeric and mesic woodlands at ONSR. 


\section{Understory Tolerance}

Although the number of understory-tolerant and intermediately understory-tolerant species examined was similar (12 and 10, respectively), there were proportionally more seedlings of the intermediately understory-tolerant species than the understory-tolerant ones. However, the understory-intolerant seedlings, representing only 8 species, were most abundant. Thus, the number of seedlings of understory-intolerant species account for the greatest proportion of seedlings sampled, followed by seedlings of intermediatelyunderstory-tolerant species, then understory-tolerant species. This is true both overall and for each natural community type (Figure 2). 

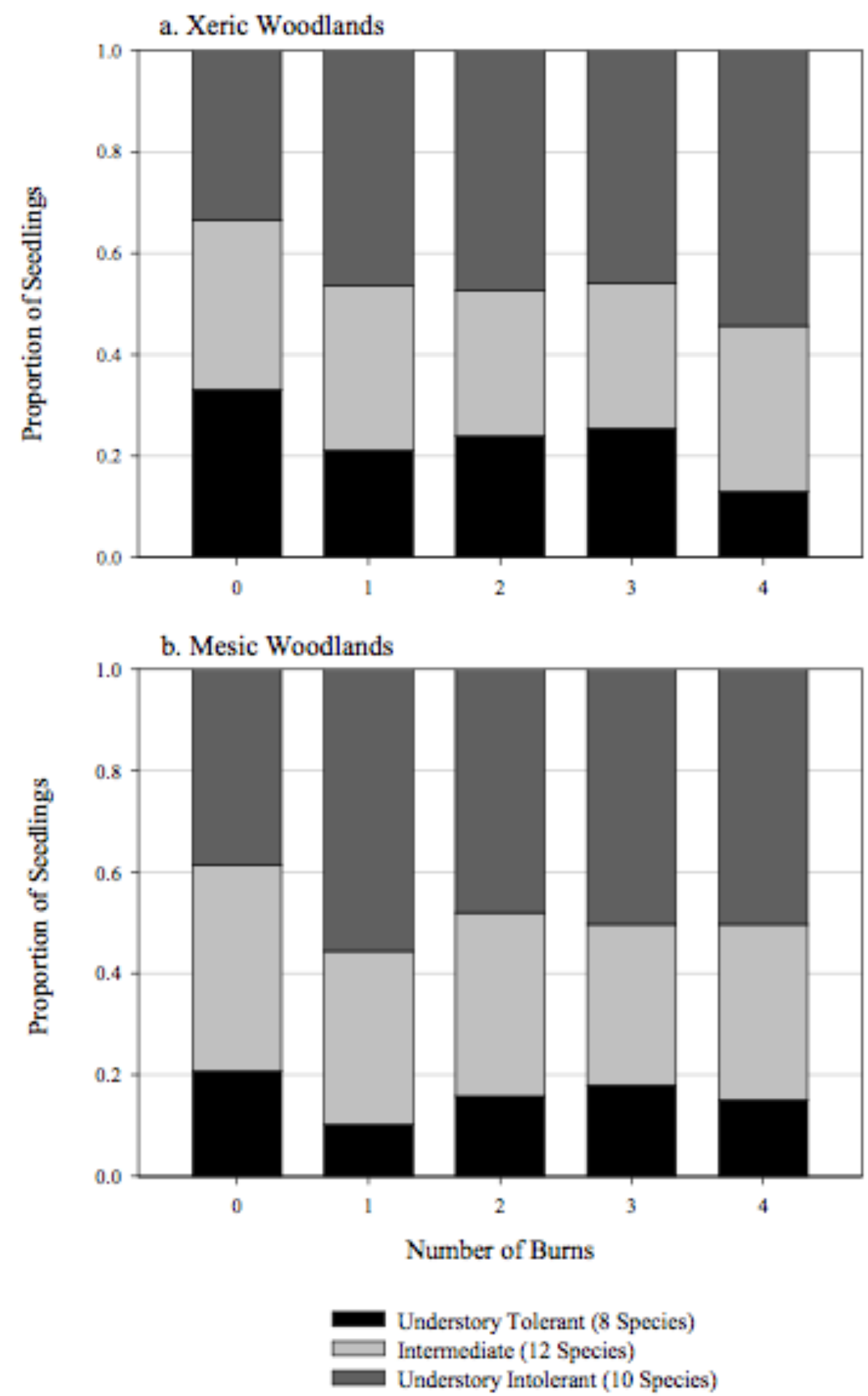

Figure 6. Proportions of understory-tolerant, intermediately-tolerant, and understory-intolerant seedling species in a.) xeric and b.) mesic woodlands at ONSR after increasing number of burns. In both natural communities, understoryintolerant species comprised the greatest proportion of all seedlings sampled. 
Understory-Tolerant Species. Overall density of understory-tolerant seedlings was only slightly greater in xeric woodlands, compared to mesic woodlands. Pre-burn densities between natural communities were not significantly different, but densities after the first and second burns were. There was no difference between densities after the fourth burn (Figure 3a) (Table 12).

In xeric woodlands, no understory-tolerant seedling densities were significantly different compared to the previous burn density, and there was not a significant difference when comparing pre-burn seedling density to density after the fourth burn in xeric plots. In mesic woodlands, seedling density significantly decreased after the first burn, compared to pre-burn density, but then remained unchanged through the fourth burn. The comparison of pre-burn density to that after the fourth burn was not significant (Table 13).

Intermediately Understory-Tolerant Species. None of the differences between natural communities were significant for any level of treatment (Figure 3b) (Table 12).

In xeric woodlands, seedling density increased slightly from pre-burn to after 1 burn, decreased slightly from 1 to 2 and 2 to 3 burns, then increased slightly from 3 to 4 burns. None of these changes were significant, after adjusting for multiple comparisons, although seedling density marginally increased from the third to fourth burn. Intermediately tolerant seedling density in xeric woodlands was significantly greater after the fourth burn, compared to pre-burn density. In mesic woodlands, none of the 
differences in seedling density were significant, when compared to the previous sampling density. Pre-burn density and density after the fourth burn were not significantly different in mesic woodlands. 
Table12. $t$-values and Tukey-Kramer adjusted P-values for understory tolerance, when comparing xeric and mesic woodlands, after repeated fire. For all comparisons, $\alpha=0.05$.

\begin{tabular}{|c|c|c|c|c|c|c|}
\hline \multirow[b]{2}{*}{$\begin{array}{c}\text { Understory } \\
\text { Tolerance }\end{array}$} & \multirow[b]{2}{*}{$\begin{array}{c}\text { Statistical } \\
\text { Comparisons }\end{array}$} & \multicolumn{5}{|c|}{ Number of Fires } \\
\hline & & $\begin{array}{l}\text { Pre- } \\
\text { Fire }\end{array}$ & 1 Fire & 2 Fires & 3 Fires & 4 Fires \\
\hline \multirow{2}{*}{ Tolerant } & $t$-value & 2.44 & 4.07 & 4.66 & 2.39 & 0.33 \\
\hline & Adusted $P<|t|$ & 0.3046 & 0.0021 & 0.0002 & 0.9980 & 1.0000 \\
\hline \multirow{2}{*}{ Intermediate } & $t$-value & -3.07 & -2.28 & -1.22 & -0.84 & 0.38 \\
\hline & Adusted $P<|t|$ & 0.068 & 0.4032 & 0.9695 & 0.998 & 1.0000 \\
\hline \multirow{2}{*}{ Intolerant } & $t$-value & -2.48 & -3.46 & -0.07 & -0.74 & 0.05 \\
\hline & Adusted $P<|t|$ & 0.2837 & 0.0203 & 1.0000 & 0.9993 & 1.0000 \\
\hline
\end{tabular}

Table13. $t$-values and Tukey-Kramer adjusted P-values for understory tolerance, when comparing repeated fires in xeric or mesic woodlands. For all comparisons, $\alpha=0.05$.

\begin{tabular}{|c|c|c|c|c|c|c|c|}
\hline \multirow[b]{2}{*}{$\begin{array}{l}\text { Understory } \\
\text { Tolerance }\end{array}$} & \multirow[b]{2}{*}{$\begin{array}{c}\text { Natural } \\
\text { Community }\end{array}$} & \multirow[b]{2}{*}{$\begin{array}{c}\text { Statistical } \\
\text { Comparisons }\end{array}$} & \multicolumn{5}{|c|}{ Fire Comparisons } \\
\hline & & & $\begin{array}{c}\text { Pre- } \\
\text { burn to } \\
1 \text { Fire }\end{array}$ & $\begin{array}{l}1 \text { to } 2 \\
\text { Fires }\end{array}$ & $\begin{array}{l}2 \text { to } 3 \\
\text { Fires }\end{array}$ & $\begin{array}{l}3 \text { to } 4 \\
\text { Fires }\end{array}$ & Overall \\
\hline \multirow{4}{*}{ Tolerant } & \multirow{4}{*}{$\begin{array}{c}\text { Xeric } \\
\text { Woodlands } \\
\text { Mesic } \\
\text { Woodlands }\end{array}$} & $t$-value & 0.90 & -0.89 & 0.51 & 1.00 & 1.63 \\
\hline & & Adusted $P<|t|$ & 0.9966 & 0.9967 & 1.0000 & 0.9920 & 0.8357 \\
\hline & & $t$-value & 3.32 & -0.24 & -0.95 & -0.41 & 0.49 \\
\hline & & Adusted $P<|t|$ & 0.0315 & 1.0000 & 0.9945 & 1.0000 & 1.0000 \\
\hline \multirow{4}{*}{ Intermediate } & \multirow{4}{*}{$\begin{array}{c}\text { Xeric } \\
\text { Woodlands } \\
\text { Mesic } \\
\text { Woodlands }\end{array}$} & $t$-value & -2.18 & 1.08 & 0.77 & -3.14 & -3.56 \\
\hline & & Adusted $\mathrm{P}<|\boldsymbol{t}|$ & 0.4733 & 0.9866 & 0.9989 & 0.0143 & 0.0143 \\
\hline & & $t$-value & -1.54 & 1.78 & 0.71 & -0.85 & -0.23 \\
\hline & & Adusted $P<|t|$ & 0.8751 & 0.7446 & 0.9995 & 0.9976 & 1.0000 \\
\hline \multirow{4}{*}{ Intolerant } & \multirow{4}{*}{$\begin{array}{c}\text { Xeric } \\
\text { Woodlands } \\
\text { Mesic } \\
\text { Woodlands }\end{array}$} & $t$-value & -4.19 & 0.19 & 1.15 & -3.36 & -5.67 \\
\hline & & Adusted $P<|t|$ & 0.0014 & 1.0000 & 0.9792 & 0.0287 & $<0.0001$ \\
\hline & & $t$-value & -4.10 & 2.30 & -0.07 & -0.74 & 1.68 \\
\hline & & Adusted $\mathrm{P}<|\boldsymbol{t}|$ & 0.0019 & 0.3907 & 1.0000 & 0.9992 & 0.8046 \\
\hline
\end{tabular}


Understory-Intolerant Species. Seedling densities of understory-intolerant species were not significantly different between natural communities, for any treatment level (Figure 3c). In xeric woodlands, the number of understory-intolerant species increased significantly after 1 burn, compared to the pre-burn density, but there were no other statistically significant differences between treatments. Overall, the increase of understory-intolerant seedling density in xeric woodlands from pre-burn to after the fourth burn was highly significant.

In mesic woodlands, there was a significant increase in seedling density after the first burn, when compared to pre-burn density, but no other burn-to-burn comparisons were significant. There was not a significant difference in density when comparing preburn to after the fourth burn in mesic woodlands. 

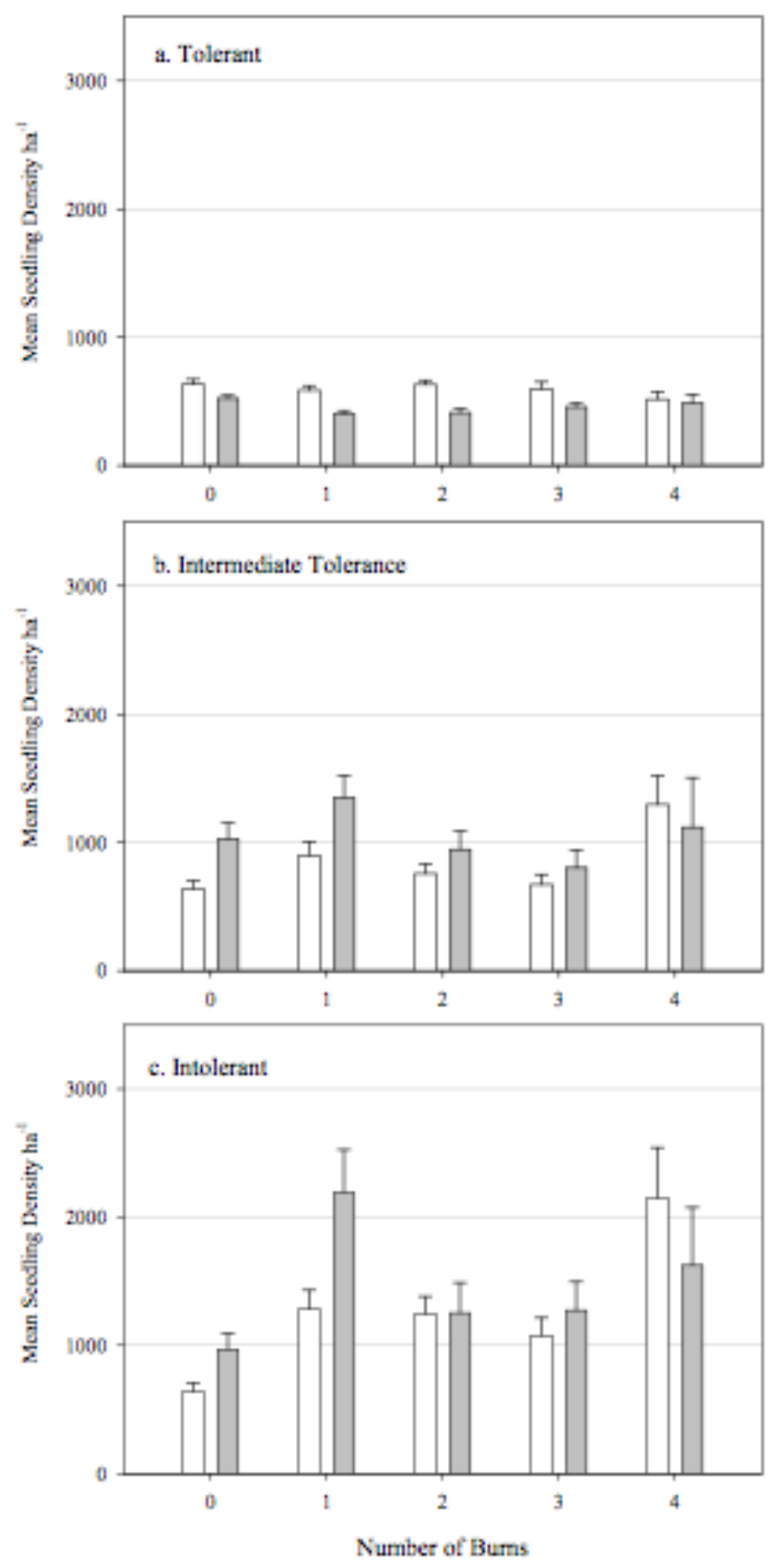

Figure 7. Mean seedling density ha-1 in xeric and mesic woodlands for a.) understory-tolerant, b.) intermediatelytolerant, and c.) understory-intolerant seedling species, across increasing number of prescribed burns, at OSNR. 


\section{Fire Tolerance}

Fire-tolerant seedling density was proportionally highest, compared to intermediate and intolerant seedling densities. Of the 29 species examined, 11 were considered firetolerant and 13 intermediately tolerant, implying that fire-tolerant species were accounting for more of the overall seedling density per species. Few (6) species were considered to be fire-intolerant; seedling densities of these species were quite low, in both natural communities, and comprised only a small proportion of overall density (Figure 4).

Fire-Tolerant Species. Seedling density of fire-tolerant species was greater in mesic woodlands than xeric woodlands pre-burn, but no other comparisons were significant (Figure 5a) (Table 14).

Significant differences existed between some burns in xeric woodlands. Firetolerant seedling density increased after the first burn, compared to pre-burn density, decreased insignificantly between 1-2 and 2-3 burns, then significantly increased after the fourth burn, compared to the third. Seedling density increased significantly from the preburn to after the fourth burn. None of the differences between densities were significant in mesic woodlands (Table 15). 
a. Xeric Woodlands

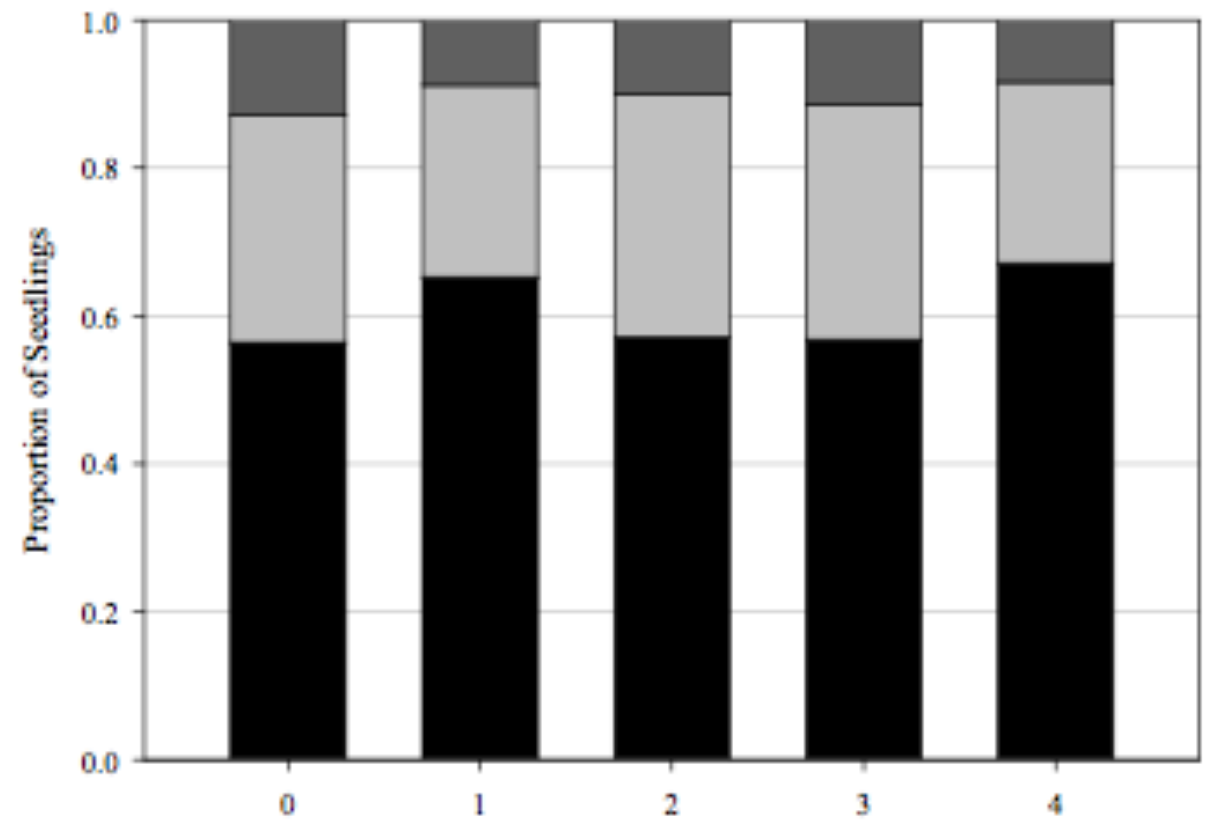

b. Mesic Woodlands

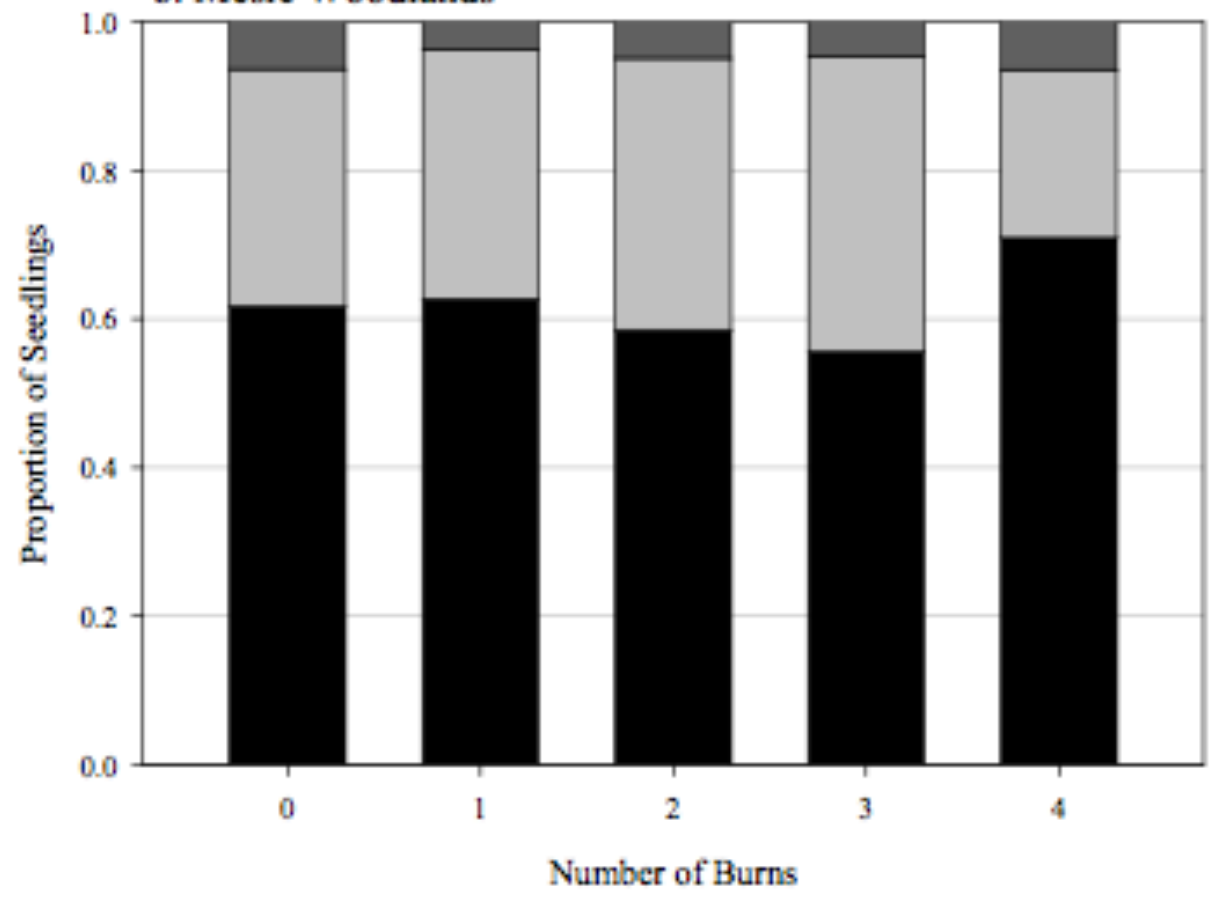

Fire Tolerant (11 Species)

Intermediate (13 Species)

Fire Intolerant ( 6 Species)

Figure 8. Proportions of fire-tolerant, intermediately-tolerant, and fire-intolerant seedling species in a.) xeric and b.) mesic woodlands at ONSR after increasing number of burns. In both natural communities, fire-tolerant species comprised the greatest proportion of seedlings. 
Table 14. $t$-values and Tukey-Kramer adjusted P-values for fire tolerance, when comparing xeric and mesic woodlands, after repeated fire. For all comparisons, $\alpha=0.05$.

\begin{tabular}{|c|c|c|c|c|c|c|}
\hline \multirow{2}{*}{$\begin{array}{c}\text { Fire } \\
\text { Tolerance }\end{array}$} & \multirow{2}{*}{$\begin{array}{c}\text { Statistical } \\
\text { Comparisons }\end{array}$} & \multicolumn{5}{|c|}{ Number of Fires } \\
\hline & & $\begin{array}{l}\text { Pre- } \\
\text { Fire }\end{array}$ & 1 Fire & $\begin{array}{c}2 \\
\text { Fires } \\
\end{array}$ & $\begin{array}{c}3 \\
\text { Fires } \\
\end{array}$ & 4 Fires \\
\hline \multirow{2}{*}{ Tolerant } & $t$-value & -3.6 & -2.53 & -1.68 & -2.05 & 0.23 \\
\hline & Adusted $P<|t|$ & 0.0122 & 0.2553 & 0.087 & 0.5642 & 1.0000 \\
\hline \multirow{2}{*}{ Intermediate } & $t$-value & -1.62 & -2.48 & -1.31 & -1.76 & 0.32 \\
\hline & Adusted $P<|t|$ & 0.8398 & 0.2085 & 0.9502 & 0.7609 & 1.0000 \\
\hline \multirow{2}{*}{ Intolerant } & $t$-value & 1.86 & 2.47 & 2.1 & 1.15 & 0.84 \\
\hline & Adusted $P<|t|$ & 0.6961 & 0.2879 & 0.5290 & 0.9879 & 0.9978 \\
\hline
\end{tabular}

Table 15. $t$-values and Tukey-Kramer adjusted P-values for fire tolerance, when comparing repeated fires in xeric or mesic woodlands. For all comparisons, $\alpha=0.05$.

\begin{tabular}{|c|c|c|c|c|c|c|c|}
\hline \multirow[b]{2}{*}{$\begin{array}{c}\text { Fire } \\
\text { Tolerance }\end{array}$} & \multirow[b]{2}{*}{$\begin{array}{c}\text { Natural } \\
\text { Community }\end{array}$} & \multirow[b]{2}{*}{$\begin{array}{c}\text { Statistical } \\
\text { Comparisons }\end{array}$} & \multicolumn{5}{|c|}{ Number of Burns } \\
\hline & & & $\begin{array}{c}\text { Pre- } \\
\text { burn to } \\
1 \text { Fire }\end{array}$ & 1 to 2 & 2 to 3 & 3 to 4 & Overall \\
\hline \multirow{4}{*}{ Tolerant } & \multirow{2}{*}{$\begin{array}{c}\text { Xeric } \\
\text { Woodlands }\end{array}$} & $t$-value & -3.93 & 1.49 & 1.84 & -3.92 & -4.47 \\
\hline & & Adusted $\mathrm{P}<|\boldsymbol{t}|$ & 0.0036 & 0.0004 & 0.7101 & 0.0037 & 0.0004 \\
\hline & \multirow{2}{*}{$\begin{array}{c}\text { Mesic } \\
\text { Woodlands }\end{array}$} & $t$-value & -2.62 & 1.61 & 0.92 & -0.99 & -0.76 \\
\hline & & Adusted $P<|t|$ & 0.2103 & 0.8423 & 0.9958 & 0.9930 & 0.9991 \\
\hline \multirow{4}{*}{ Intermediate } & \multirow{2}{*}{$\begin{array}{c}\text { Xeric } \\
\text { Woodlands }\end{array}$} & $t$-value & -0.69 & -0.88 & 1.19 & -0.55 & -0.69 \\
\hline & & Adusted $P<|t|$ & 0.9995 & 0.997 & 0.9731 & 0.9999 & 0.9995 \\
\hline & \multirow{2}{*}{$\begin{array}{c}\text { Mesic } \\
\text { Woodlands }\end{array}$} & $t$-value & -2.25 & -0.57 & 0.14 & 1.17 & 0.68 \\
\hline & & Adusted $P<|\boldsymbol{t}|$ & 0.4231 & 0.9999 & 1.0000 & 0.9769 & 0.9996 \\
\hline \multirow{4}{*}{ Intolerant } & \multirow{2}{*}{$\begin{array}{c}\text { Xeric } \\
\text { Woodlands }\end{array}$} & $t$-value & 0.18 & -0.31 & 0.22 & -0.30 & -0.28 \\
\hline & & Adusted $P<|t|$ & 1.0000 & 1.0000 & 1.0000 & 1.0000 & 1.0000 \\
\hline & \multirow{2}{*}{$\begin{array}{c}\text { Mesic } \\
\text { Woodlands }\end{array}$} & $t$-value & 1.64 & -0.63 & 1.20 & -1.31 & -0.23 \\
\hline & & Adusted $\mathrm{P}<|\boldsymbol{t}|$ & 0.8245 & 0.9998 & 0.9725 & 0.9507 & 1.0000 \\
\hline
\end{tabular}


Intermediately Fire-Tolerant Species. No significant differences were found between xeric and mesic species or after any number of burns (Figure 5b) (Table 15).

There were no significant differences in intermediately tolerant seedling density in xeric woodlands. Pre-burn density and the density after the fourth burn were not significantly different. As with the xeric woodlands, there were no significant differences in the density of intermediately fire-tolerant seedlings after any treatments. Pre-burn density was not significantly different from that after the fourth burn.

Fire-Intolerant Species. Density of fire-intolerant seedlings was slightly greater in xeric woodlands than in mesic woodlands, but no differences between the natural communities were significant for any burn treatments (Figure 5c) (Table 15).

There were no differences in the fire-intolerant seedling densities in xeric woodlands after each treatment, nor was the overall difference significant, comparing the pre-burn density to that after the fourth burn. No significant differences existed between the densities in mesic woodlands, either, along with the overall difference from pre-burn density to density after the fourth burn. 

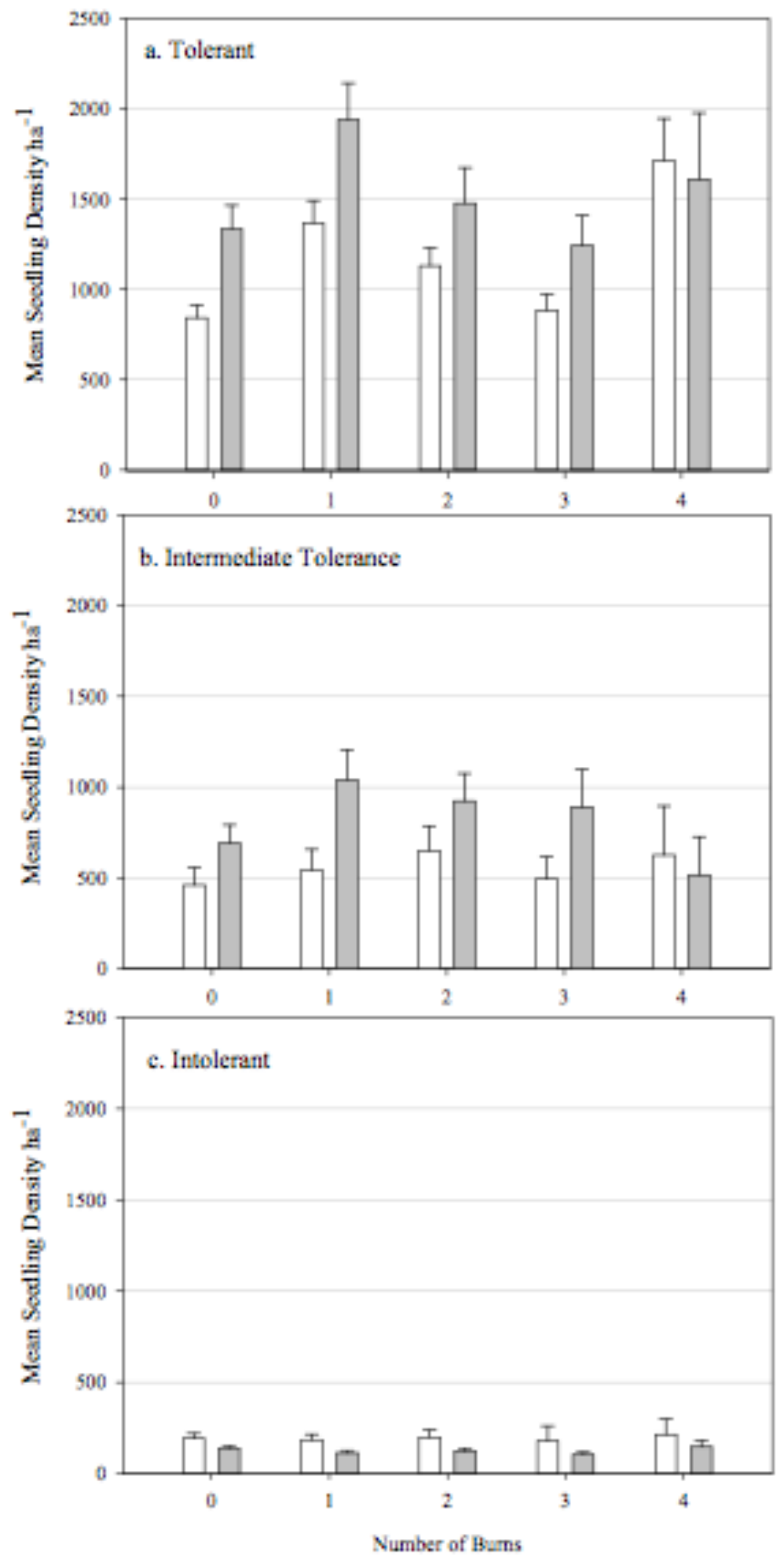

Figure 9. Mean seedling density ha ${ }^{-1}$ in xeric and mesic woodlands for a.) fire-tolerant, b.) intermediately-tolerant, and c.) fire-intolerant seedling species, across increasing number of prescribed burns, at OSNR. 


\section{DISCUSSION}

The greater preponderance of seedlings in mesic woodlands, compared to xeric woodlands, was expected, regardless of the impacts of fire. Seedlings of any of the 30 species examined, and of most tree species, are better able to germinate and produce aerial growth in more favorable soil conditions associated with mesic woodlands. In terms of the impacts of repeated burning on seedling density, overall, the trend in both xeric and mesic woodlands was similar. The increase from pre-burn to after the first burn is likely due to several factors, including a nutrient release from the fire, the removal of a thick litter layer that may have prevented germination, and a slight release from competition from other woody or herbaceous plants in the understory (Burton et al. 2011, Abrams and Steiner 2013).

The effects seen after the first burn did not carry through time evenly; after the second and third burns, no changes in seedling density were significant for either natural community. Seedling density in xeric woodlands increased significantly after the fourth burn, compared to pre-burn density. In mesic woodlands, unlike in xeric woodlands, seedling density after the fourth burn had returned to that of pre-burn levels. This indicates that the prescribed fire regime is potentially increasing seedling density on xeric sites, but not affecting density on mesic sites. Greater fire intensity, in combination with slower regeneration of herbaceous ground flora on xeric sites, likely allowed tree seedlings to dominate over time, while competing herbaceous species were most likely able to rebound better in the mesic woodlands.

Few significant differences were found in the density of individual oak, pine, and 
hickory species, between natural communities or after repeated burns. Black hickory seedlings were more prevalent in mesic woodlands pre-burn, but increased in xeric woodlands and decreased in mesic woodlands after four burns. This was the strongest response to treatment for any individual species. Mockernut hickory and black oak densities were greater in xeric woodlands than mesic, after one burn, but these differences stood alone. Repeated burning does not seem to affect individuals of most species of oak, hickories, and pines at ONSR, when examined at the species level. This indicates that prescribed fire may not affect seedling community composition at a species level, but, rather, at the functional life-history level - that is, individual species do not seem to increase or decrease with the use of prescribed fire, but groups of similar species may.

Although over $1 / 3$ of species examined were understory-tolerant, the proportional density of seedlings of these species was small; this was the case with intermediately understory-tolerant species, as well. There were more understory-tolerant seedlings in xeric woodlands, compared to mesic woodlands, and more intermediately tolerant seedlings in mesic woodlands, until after the fourth burn. Although there were natural community differences, neither of these groups showed significant changes from burn to burn, indicating that the seedling density is not changing over time in either natural community. These results are to be expected, as the continued application of prescribed fire at low- to moderate intensities would not necessarily affect the density of seedlings of various understory tolerances, unless significant canopy removal took place.

Understory-tolerant species are considered to be late-successional due to their ability to persist in the understory as seedlings; low seedling density after continued fire 
treatment suggests that, although fire may not be having an impact, recruitment into the overstory at ONSR is unlikely. Were fire creating large gaps or canopy openings, understory-tolerant species would be able to take advantage; however, fires do not seem to be causing enough of a release from light or other competition, thereby keeping understory-tolerant specie in the understory. Since fire does not seem to impact the density of understory-tolerant seedlings, other factors must be influencing the recruitment of the understory-tolerant species, including limiting factors inherent to the Ozark highlands, such as the nutrient-deficient shallow soils, which are unsuitable for the growth and persistence of mature individuals of mesophytic species, or topographical effects, such as rapid water runoff (Batek et al. 1999, Nigh and Schroeder 2002, Dey and Hartman 2005).

Intermediately understory-tolerant species increased in density in xeric woodlands, but not in mesic woodlands. In this case, prescribed fire is likely creating favorable conditions that allow these species to slowly take advantage of released light and nutrient resources on the drier xeric sites, but not necessarily in the richer mesic areas; this follows the expectations of competitive exclusion in xeric versus mesic areas (Abrams 1990, Nowacki and Abrams 2008). Additionally, several intermediately-tolerant species require a small or non-existent litter layer for germination (Burns and Honkala 1990); periodic prescribed fire would, therefore, favor these species, as litter is almost always consumed in surface fires in oak-dominated systems (Kolaks et al. 2004).

Although only 8 of the 30 species were considered understory-intolerant, these seedlings comprised the highest proportion of seedlings sampled. Understory-intolerant species are typically pioneering and early-successional, and can respond to disturbances 
that release individuals from competition. Density of these seedlings was only slightly greater in mesic woodlands after the first burn, but, otherwise, was similar between natural communities. There was no significant overall change in the density of understory-intolerant seedlings in mesic woodlands, and, except for a single burn, no changes between treatments. Seedling density in xeric woodlands increased, however, indicating that the repeated fires, which act as succession-resetting disturbances are possibly impacting the density of fast-growing species' seedlings by creating opportunities for post-fire colonization.

In terms of fire-tolerant species, pre-burn seedling density was greater in mesic woodlands than in xeric woodlands, but no other significant differences between natural communities were found. Overall, seedling density of fire-tolerant species increased in xeric woodlands, whereas mesic woodlands did not exhibit this pattern. Thus, in xeric woodlands, it is possible that prescribed fire is promoting the increased mean density of seedlings belonging to fire-tolerant species, but is having no apparent effect in mesic woodlands. Prescribed fire may be working in tandem with other life-history traits of these species, such as drought tolerance, or conditions of the physical environment, that promote fire-tolerant species. Fire-tolerant species developed in the area because of the historic fire regime (Abrams 1992, Guyette et al. 2002, Nigh and Schroeder 2002), and have persisted, although the fire regime and land use have changed several times in the last four hundred years (Keefe 1987, Batek et al. 1999, Guyette et al. 2002). It is unsurprising to find fire-tolerant species throughout the Ozark Highlands, although firetolerance does not mean a species is fire-dependent. Fire-tolerant species are those that can persist under periodic fire conditions, and even benefit from changes caused by fires 
(like sassafras), whereas fire-dependent species require fire to propagate (most oaks and pines are assumed to be fire-dependent for regeneration).

Intermediately fire-tolerant seedling densities were not different between xeric and mesic woodlands, nor were there any effects apparent due to repeated burning. The majority of species examined fell into this group (13 of 29), but the proportion of overall seedling density was less than that of fire-tolerant species. Fire is apparently not affecting the densities of the recruitment of seedlings belonging to these species. These results also applied to the fire-intolerant species: no differences between natural communities or burn treatments were significant. Only 6 species were in this group, but the proportion of mean density accounted for was low. As with the predominance of fire-tolerant species at ONSR, this fits in with the expectation that there would be few fire-intolerant species in an area with frequent historical fires (Guyette et al. 2002, Nigh and Schroeder 2002, Stambaugh and Guyette 2006). 


\section{MANAGEMENT IMPLICATIONS}

Mesophication of eastern oak woodlands and forests (Nowacki and Abrams 2008), as well as a lag in the recruitment of advance regeneration of important overstory species and the decline of established trees in several areas (Shifley et al. 2006, Kabrick et al. 2008, Fan et al. 2011), are important considerations when developing management practices. It is presumed that oak-dominated woodlands and forests require fire for their management and propagation (Abrams 1992, Hutchionson et al. 2012), or, at least, that oak regeneration responds best to management including prescribed fire (Abrams and Downs 1990, Albrecht and McCarthy 2006, Anning and McCarthy 2013), but no longterm studies have examined the influence of fire on the densities of seedlings in the absence of timber harvest, on xeric and mesic sites in the same region. In the Missouri Ozarks, mesophication has been less of an issue due to the unsuitable soil and tophographical characteristics of the area, which prevent mesophytic species that are strong competitors in other areas of the Central Hardwoods and Eastern Deciduous Forest from being recruited into the overstory. The results of this study, which showed that understory-tolerant and primarily fire-intolerant species are unaffected by fire and occur only in low densities across ONSR, support the idea that mesophication is not presently an issue to contend with in the Ozark Highlands.

The more pertinent issue at ONSR and in the Ozarks is the recruitment of species assumed to be fire-tolerant (oaks, hickories, and shortleaf pine) into the overstory. Typically, oak species are grouped together into a single group when being assessed as to

their understory tolerance or response to fire; however, due to the dominance of several oak species at ONSR, this study sought to override the assumption that all oak species 
respond the same. Categorizing individual species, rather than entire genera, will allow managers at ONSR to see their impacts at a finer resolution.

While some oak and hickory species seemed to respond to prescribed fire treatment, most did not. This makes comparing groups of understory and fire tolerance more important, as the response of groups of species sharing functional traits may prove more important, in terms of managing seedling regeneration, than the responses of individual species alone. Prescribed fire, for example, may be helpful in promoting intermediately understory-tolerant and understory-intolerant species in xeric woodlands, over time. These groups together include each of the oaks and hickories, as well as shortleaf pine. A difference that would be overlooked by grouping oaks together, however, is that the only oak species in the intolerant group - which had the highest proportional seedling density - are blackjack, post, and scarlet oaks. All of the other oaks, and all of the hickory species at ONSR, exhibit intermediate understory tolerance as seedlings. It follows, then, that the prescribed fire program, though increasing seedling density of all oak, pine, and hickory species, is disproportionately increasing the density of only a few oak species compared to the rest. Light competition may be an important factor in the growth of seedlings in several areas, but fire- and other stress-related tolerances seem to be more limiting at ONSR than light availability or indirect competition.

From the angle of fire tolerance, most oak species were classified as fire-tolerant; however, one species was intermediately tolerant - scarlet oak - which was also the most understory-intolerant species. Thus, one third of the pioneering oak species are less firetolerant than all of the other oak species found at ONSR. Based on the life-history 
characteristics of scarlet oaks, it is likely that currently reproductive overstory individuals were established during a time of fire suppression (likely during the stand reinitiation that began in the mid-1900s, when the fire return interval was greatest - see Guyette et al. 2002. Currently, prescribed fire at ONSR may be disproportionately favoring seedlings of post oaks, while only moderately favoring other oak and hickory advance regeneration on xeric sites. This is an issue because these species are not commonly found in the overstory at ONSR.

The fire program at ONSR may be promoting seedlings of species that are able to grow and outcompete in especially stressful situations, such as post oak, while causing other species to be excluded from xeric woodlands, due either to competition or repeated top-kill from prescribed fires. Xeric areas in the Missouri Ozarks have rocky, shallow soil, low nutrient availability, and drain quickly (Keefe 1987, Nigh and Schroeder 2002, Nelson 2005); these conditions are stressful for establishing advance regeneration, and, in combination with overly-frequent fire, can remove advance regeneration of any stressed, slow-growing overstory species, even those that are fire-tolerant. A loss of the currently dominant overstory oak species at ONSR would cause a decrease in native species richness, as well as a shift in understory vegetation. Since burn goals at ONSR include the maintenance or increase of native species richness, a change in the fire regime may be necessary to achieve that goal.

The findings of this study, along with supporting evidence that oak regeneration is more likely on xeric sites in the eastern United States without management or other interference (Abrams 1992) and that woodland mesophication is not currently an issue at ONSR, lead to the conclusion that the return interval between prescribed burns needs to 
be lengthened, perhaps to longer than ten years. Doing so would reduce stress on advance regeneration on xeric sites (greater than the average current interval of about 4 years), potentially allowing seedlings to be recruited into the sapling stage, in which aboveground, fire-induced mortality is no longer inevitable. Intermediately-frequent single-tree or group-selection thinning events, coupled with lengthened return intervals, would also likely benefit advance regeneration of understory-intolerant and intermediately-tolerant overstory tree species (including oaks, shortleaf pine, and hickories) by indirectly reducing competition for light. More long-term research needs to be done to continue examining the effects of prescribed fire on advance regeneration at ONSR, including the following of individuals through time to determine directly how recruitment is affected by prescribed fire. 


\section{LITERATURE CITED}

Abrams, M.D. 1992. Fire and the development of oak forests. BioScience 42(5): 346-353.

Abrams, M.D. 1998. The red maple paradox. BioScience 48: 355-364.

Abrams, M.D. 2003. Where has all the white oak gone? BioScience 53: 927-939.

Abrams, M.D. and Steiner, K.C. 2013. Long-term seedling height growth and compositional changes following logging and wildfire in a central Pennsylvania oak forest. Castanea 78(4): 256-265. doi:10.2179/13-016.

Agee, J.K. 1996. Fire ecology of Pacific Northwest forests. Island Press: The Center for Resource Economics. 505p.

Anderson, R.C. 1998. Overview of Midwestern oak savanna. Transactions of the Wisconsin Academy of Sciences, Arts, and Letters 86: 1-18.

Batek, M.J., Rebertus, A.J., Schroeder, W.A., Haithcoat, T.L., Compas, E., and Guyette, R.P. 1999. Reconstruction of early nineteenth-century vegetation and fire regimes in the Missouri Ozarks. J. Biogeography 26(2): 397-412.

Burns, R.M., and Honkala, B.H. Technical Coordinators. 1990. Silvics of North America. Vol. 2. Hardwoods. US. Dep. Agric. Agric. Handb. 654pp.

Burton, J.A., Hallgren, S.W., Fuhlendorf, S.D., and Leslie, D.M. Jr. 2011. Understory response to varying fire frequencies after 20 years of prescribed burning in an upland oak forest. Plant Ecol. 212: 1513-1525.

Carey, J.J. 1992. Quercus marilandica. In: Fire Effects Information System [Online]. US. 
Dept. Agric. Forest Service, RMRS, Fire Sciences Laboratory (Producer). Available http://www.feis-crs.org/beta/ [accessed 5 May 2014].

Conover, W.J., and Iman, R.L. 1981. Rank transformations as a bridge between parametric and nonparametric statistics. Am. Stat. 35(3): 124-129. doi: 10.1080/00031305.1981.10479327.

Cottam, G. 1949. The phytosociology of an oak woods in southwestern Wisconsin. Ecology 30: 271-147.

Cutter, B.E. and Guyette, R.P. 1994. Fire frequency on an oak-hickory ridgetop in the Missouri Ozarks. Am. Midl. Nat. 132(2): 393-398.

Dey, D.C. and Hartman, G. 2005. Returning fire to Ozark Highland forest ecosystems: effects on advance regeneration. For. Ecol. Manage. 217(1): 37-53. doi:10.1016/j.foreco.2005.05.002.

Fan, Z., Kabrick, J.M., Spetich, M.A., Shifley, S.R., and Jensen, R.G. 2011. Oak mortality associated with crown dieback and oak borer attack in the Ozark Highlands. For. Ecol. Manage. 255: 2297-2305. doi:10.1016/j.foreco.2007.12.041.

Fei, S. and Steiner, K.C. 2007. Evidence for the increasing red maple abundance in the eastern United States. Forest Sci. 252: 201-207.

Guyette, R.P., Muzika, R.M., and Dey, D.C. 2002. Dynamics of an anthropogenic fire regime. Ecosystems 5: 472-486.

He, H.S. and Mladenoff, D.J. 1999. Spatially explicit and stochastic simulation of forst- 
landscape fire disturbance and succession. Ecology 80(1): 81-99.

Hutchinson, T.F., Long, R.P., Rebbeck, J., Sutherland, E.K., and Yaussy, D.A. 2012. Repeated prescribed fires alter gap-phase regeneration in mixed-oak forests. Can. J. For. Res. 42: 303-314. doi:10.1139/X11-184.

Iverson, L.R., Dale, M.E., Scott, C.T., and Prasad, A. 1997. A GIS-derived integrated moisture index to predict forest composition and productivity in Ohio forests. For. Ecol. Manage. 218: 210-228.

Iverson, L.R., Hutchinson, T.F., Prasad, A.M., and Peters, M.P. 2007. Thinning, fire, and oak regeneration across a heterogeneous landscape in the eastern U.S.: 7-year results. For. Ecol. Manage. 255: 3035-3050. doi:10.1016/j.foreco.2007.09.088.

Johnson, P.S. 1990. Quercus coccinea Muenchh. In: Burns, R.M., and Honkala, B.H. Technical Coordinators. 1990. Silvics of North America. Vol. 2. Hardwoods. US. Dep. Agric. Agric. Handb.: 625-630.

Kabrick, J.M., Dey, D.C., Jensen, R.G., and Wallendorf, M. 2008. The role of environmental factors in oak decline and mortality in the Ozark Highlands. For. Ecol. Manage. 255: 1409-1417. doi:10.1016/j.foreco.2007.10.054.

Keefe, J.M. 1987. The first 50 years. Missouri Department of Conservation, Jefferson City, Missouri.

Klein, R., Putnam, C., Grant, V., and Soleim, D. 1999. FMH-4: Monitoring Type Description Sheets: OZAR. Ozark National Scenic Riverways. 4p.

Kolaks, J.J., Cutter, B.E., Loewenstine, E.F., Grabner, K.W., Hargnam, G.W., and 
Kabrick, J.M. 2004. The effect of thinning and prescribed fire on fuel loading in the Central Hardwood Region of Missouri. In: Proceedings of the $14^{\text {th }}$ Central Hardwood Forest Conference, GTR-NE-316: 168-178.

Ladd, D. 1991. Reexamination of the role of fire in Missouri oak woodlands. Pp. 67-80. In: Proc. Oak Woods Management Workshop. Eastern Illinois University, Charleston.

Lorimer, C.G. 1984. Development of the red maple understory in Northeastern oak forests. Forest Sci. 30(1): 3-22.

Lorimer, C.G., Chapman, J.W., and Lambert, W.D. 1994. Tall understory vegetation as a factor in the poor development of oak seedlings beneath mature stands. J. Ecol. 82: $227-237$.

McEwan, R.W., Hutchinson, T.F., Long, R.P., Ford, R.D., and McCarthy, B.C. 2007. Temporal and spatial patterns of fire occurrence during the establishment of missed-oak forests in eastern North America. J. Veg. Sci. 18(5): 655-664. doi:10.1111/j.1654-1103.2007.tb02579.x.

Nelson, P.W. 2005. The terrestrial natural communities of Missouri. S. Holst, ed. (Revised Edition). Missouri Natural Areas Committee. 550p.

Nigh, A.N., Pflieger, W.L., Redfern, P.L., Schroder, W.A., Templeton, A.R., and Thompson, F.R. 1992. The biodiversity of Missouri. Missouri Dept. Cons., Jefferson City. 53p.

Nigh, T.A. and Schroeder, W.A. 2002. Atlas of Missouri Ecoregions. The Conservation 
Commission, State of Missouri; Missouri Department of Conservation, Jefferson City, MO. 212pp.

Nowacki, G.J. and Abrams, M.D. 2008. The demise of fire and "mesophication" of forests in the eastern United States. BioScience 58(2): 123-138. doi:10.1641/B580207.

Price, J.E. 2013. Ozark National Scenic Riverways: The preservation of two wild and scenic rivers [online]. Available from http://www.nps.gov/ozar/historyculture/establishment.htm [accessed 13 March 2014].

Pyne, S.J., Andrews, P.L., and Laven, R.D. 1996. Introduction to wildland fire. Wiley, New York.

Rogers, R. 1990. Quercus alba. In: Burns, R.M., and Honkala, B.H. Technical Coordinators. 1990. Silvics of North America. Vol. 2. Hardwoods. US. Dep. Agric. Agric. Handb.: 605-613.

Rowe, J.S. 1983. Concepts of fire effects on plant individuals and species. In: Wein, R.W. and MacLean, D.A., eds. The role of fire in Northern Circumpolar ecosystems. Scope: John Wiley \& Sons. Pps. 135-154.

Sander, I.L. 1990a. Quercus muhlenbergii Engelm. In: Burns, R.M., and Honkala, B.H. Technical Coordinators. 1990. Silvics of North America. Vol. 2. Hardwoods. US. Dep. Agric. Agric. Handb.: 1346-1352.

Sander, I.L. 1990b. Quercus rubra L. Northern Red Oak. Burns, R.M., and Honkala, B.H. 
Technical Coordinators. 1990. Silvics of North America. Vol. 2. Hardwoods. US. Dep. Agric. Agric. Handb.: 727-733.

SAS. 2008. SAS Version 9.2 for Windows. SAS Institute Inc., Cary, N.C.

Schuster, W.S.F., Griffin, K.L., Roth, H., Turnbull, M.H., Whitehead, D., and Tissue, D.T. 2008. Changes in composition, structure and above-ground biomass over seventy-six years (1930-2006) in the Black Rock Forest, Hudson Highlands, southeastern New York State. Tree Physiol. 28: 537-549.

Shifley, S.R., Fan, Z., Kabrick, J.M., and Jensen, R.G. 2006. Oak mortality risk factors and mortality estimation. For. Ecol. Manage. 229: 16-26. doi:10.1016/j.foreco.2006.03.033.

Stambaugh, M.C. and Guyette, R.P. 2006. Fire regime of an Ozark wilderness area, Arkansas. Am. Midl. Nat. 156: 237-251.

Stranksy, J.J. 1990. Quercus stellata Wangenh. In: Burns, R.M., and Honkala, B.H. Technical Coordinators. 1990. Silvics of North America. Vol. 2. Hardwoods. US. Dep. Agric. Agric. Handb.: 738-743.

USDA Forest Service. 2014. Fire Effects Information System (FEIS). [Online.] Available from http://www.feis-crs.org/beta/ [accessed 2 May 2014].

Voelker, S.L. 2004. Causes of forest decline and consequences for oak-pine stand dynamics in southeastern Missouri. M.Sc. thesis, Department of Forestry, The University of Missouri - Columbia, Columbia, MO. 


\section{APPENDIX}

Table A1. List of the 30 species used in this study, including the taxonomic authorities and respective FEIS Database authors (contributors). Taxonomic authorities were cross-checked with the USDA NRCS Plants Database (http://plants.usda.gov) for accuracy, as authorities are commonly updated.

\begin{tabular}{|c|c|c|}
\hline Species & Family & FEIS Contributor, Year \\
\hline Acer negundo L. & Aceraceae & L.C. Rosario, 1988. \\
\hline Acer rubrum $\mathrm{L}$. & Aceraceae & D.A. Tirmenstein, 1991. \\
\hline Acer saccharum Marsh. & Aceraceae & D.A. Tirmenstein, 1991. \\
\hline Amelanchier arborea (Michx. F.) Fern. & Rosaceae & S.A. Snyder, 1992. \\
\hline Carya glabra (Mill.) Sweet & Juglandaceae & D.A. Tirmenstein, 1991. \\
\hline Carya ovate (Mill.) K. Koch & Juglandaceae & D.A. Tirmenstein, 1991. \\
\hline Carya texana Buckl. & Juglandaceae & D. Kurz, $2003 .{ }^{1}$ \\
\hline Carya tomentosa (Lam.) Nutt & Juglandaceae & M. Coladonato, 1992. \\
\hline Cornus florida $\mathrm{L}$. & Cornaceae & D.A. Tirmenstein, 1991. \\
\hline Fraxinus americana $\mathrm{L}$. & Oleaceae & R.S. Griffith, 1991. \\
\hline Fraxinus pennsylvanica Marsh. & Oleaceae & C. L. Gucker, 2005. \\
\hline Fraxinus quadrangulata Michx. & Oleaceae & D. Kurz, 2003. ${ }^{1}$ \\
\hline Juglans nigra $\mathrm{L}$. & Juglandaceae & M. Coladonato, 1991. \\
\hline Juniperus virginiana $\mathrm{L}$. & Cupressaceae & M.D. Anderson, 2003. \\
\hline Nyssa sylvatica Marsh. & Cornaceae & M. Coladonato, 1991. \\
\hline Ostrya virginiana (Mill.) K. Koch & Betulaceae & M. Coladonato, 1992. \\
\hline Pinus echinata Mill. & Pinaceae & J.H. Carey, 1992. \\
\hline Prunus serotina Ehrh. & Rosaceae & R.J. Uchytil, 1991. \\
\hline Quercus alba $\mathrm{L}$. & Fagaceae & D.A. Tirmenstein, 1991. \\
\hline Quercus coccinea Münchh. & Fagaceae & J.H. Carey, 1992. \\
\hline Quercus marilandica Münchh. & Fagaceae & J.H. Carey, 1992. \\
\hline Quercus muehlenbergii Engelm. & Fagaceae & D.A. Tirmenstein, 1991. \\
\hline Quercus rubra L. & Fagaceae & D.A. Tirmenstein, 1991. \\
\hline Quercus shumardii Buckl. & Fagaceae & J. Sullivan, 1993. \\
\hline Quercus stellata Wangenh. & Fagaceae & J.H. Carey, 1992. \\
\hline Quercus velutina Lam. & Fagaceae & J.H. Carey, 1992. \\
\hline Sassafras albidum (Nutt.) Nees & Lauraceae & J. Sullivan, 1993. \\
\hline Ulmus alata Michx. & Ulmaceae & G.A. Snow, $1990 .^{2}$ \\
\hline Ulmus americana $\mathrm{L}$. & Ulmaceae & M. Coladonato, 1992. \\
\hline Ulmus rubra Muhl. & Ulmaceae & M. Coladonato, 1993. \\
\hline
\end{tabular}

1. Data for C. texana and F. quadrangulata unavailable through FEIS; tolerances were inferred from: D. Kurz. 2003. Trees of Missouri. Missouri Dept. Cons. Jefferson City, MO. 399p.

2. Information for U. alata from Burns, R.M. and Honkala, B.H., technical coordinators. Agriculture Handbook 654. Silvics of North America. Vol. 2. Hardwoods. Washington, DC: U.S. Department of Agriculture, Forest Service. [Pages unknown.] 
Table A2. Type III sum of squares tests for fixed effects used to model overall seedling density. For all comparisons, $\alpha=0.05$.

\begin{tabular}{|c|c|c|c|c|}
\hline Effect & $\begin{array}{c}\text { Numerator } \\
\text { DF }\end{array}$ & $\begin{array}{l}\text { Denominator } \\
\text { DF } \\
\end{array}$ & $\begin{array}{c}\text { F } \\
\text { Value }\end{array}$ & $\operatorname{Pr}>F$ \\
\hline Natural Community & 1 & 2434 & 61.37 & $<0.0001$ \\
\hline Number of Burns & 4 & 2434 & 8.38 & $<0.0001$ \\
\hline $\begin{array}{c}\text { Natural Community X Number of } \\
\text { Burns(Burn Unit) }\end{array}$ & 67 & 2434 & 2.70 & $<0.0001$ \\
\hline $\begin{array}{c}\text { Natural Community X Number of } \\
\text { Burns }\end{array}$ & 4 & 2434 & 1.73 & 0.1399 \\
\hline
\end{tabular}


Table A3. Type III sum of squares tests for fixed effects used to model understory intolerant seedling density. For all comparisons, $\alpha=0.05$.

\begin{tabular}{|c|c|c|c|c|}
\hline Effect & $\begin{array}{c}\text { Numerator } \\
\text { DF } \\
\end{array}$ & $\begin{array}{c}\text { Denominator } \\
\text { DF }\end{array}$ & $\begin{array}{c}\mathbf{F} \\
\text { Value } \\
\end{array}$ & $\operatorname{Pr}>F$ \\
\hline Natural Community & 1 & 511 & 6.69 & 0.0100 \\
\hline Number of Burns & 4 & 511 & 11.80 & $<0.0001$ \\
\hline $\begin{array}{c}\text { Natural Community X } \\
\text { Number of Burns(Burn Unit) }\end{array}$ & 67 & 511 & 2.07 & $<0.0001$ \\
\hline $\begin{array}{l}\text { Natural Community X } \\
\text { Number of Burns }\end{array}$ & 4 & 511 & 1.74 & 0.1407 \\
\hline
\end{tabular}

Table A4. Type III sum of squares tests for fixed effects used to model intermediately understory tolerant seedling density. For all comparisons, $\alpha=0.05$.

\begin{tabular}{|c|c|c|c|c|}
\hline Effect & $\begin{array}{c}\text { Numerator } \\
\text { DF }\end{array}$ & $\begin{array}{c}\text { Denominator } \\
\text { DF }\end{array}$ & $\begin{array}{c}\mathbf{F} \\
\text { Value }\end{array}$ & $\operatorname{Pr}>\mathbf{F}$ \\
\hline Natural Community & 1 & 778 & 6.24 & 0.0 .0127 \\
\hline Number of Burns & 4 & 778 & 3.45 & 0.0083 \\
\hline $\begin{array}{l}\text { Natural Community X Number } \\
\text { of Burns(Burn Unit) }\end{array}$ & 67 & 778 & 3.77 & $<0.0001$ \\
\hline $\begin{array}{c}\text { Natural Community X Number } \\
\text { of Burns }\end{array}$ & 4 & 778 & 0.88 & 0.4726 \\
\hline
\end{tabular}

Table A5. Type III sum of squares tests for fixed effects used to model understory tolerant seedling density. Effects for this group were modeled using a rank transformation. For all comparisons, $\alpha=0.05$.

\begin{tabular}{|c|c|c|c|c|}
\hline Effect & $\begin{array}{l}\text { Numerator } \\
\text { DF }\end{array}$ & $\begin{array}{c}\text { Denominator } \\
\text { DF }\end{array}$ & $\begin{array}{c}\text { F } \\
\text { Value }\end{array}$ & $\operatorname{Pr}>F$ \\
\hline Natural Community & 1 & 992 & 13.31 & 0.0003 \\
\hline Number of Burns & 4 & 992 & 2.03 & 0.0883 \\
\hline $\begin{array}{l}\text { Natural Community X Number of } \\
\text { Burns(Burn Unit) }\end{array}$ & 66 & 992 & 1.08 & 0.3059 \\
\hline $\begin{array}{c}\text { Natural Community X Number of } \\
\text { Burns }\end{array}$ & 4 & 992 & 1.17 & 0.3227 \\
\hline
\end{tabular}


Table A6. Type III sum of squares tests for fixed effects used to model fire-intolerant seedling density. Effects for this group were modeled using a rank transformation. For all comparisons, $\alpha=0.05$.

\begin{tabular}{|c|c|c|c|c|}
\hline Effect & $\begin{array}{c}\text { Numerator } \\
\text { DF } \\
\end{array}$ & $\begin{array}{c}\text { Denominator } \\
\text { DF } \\
\end{array}$ & $\begin{array}{c}\text { F } \\
\text { Value } \\
\end{array}$ & $\operatorname{Pr}>$ F \\
\hline Natural Community & 1 & 32.87 & 6.99 & 0.0125 \\
\hline Number of Burns & 4 & 225.2 & 0.39 & 0.8133 \\
\hline $\begin{array}{c}\text { Natural Community X Number of } \\
\text { Burns }\end{array}$ & 4 & 225.2 & 0.15 & 0.9628 \\
\hline
\end{tabular}

Table A7. Type III sum of squares tests for fixed effects used to model intermediately fire tolerant seedling density. For all comparisons, $\alpha=0.05$.

\begin{tabular}{|c|c|c|c|c|}
\hline Effect & $\begin{array}{c}\text { Numerator } \\
\text { DF }\end{array}$ & $\begin{array}{c}\text { Denominator } \\
\text { DF }\end{array}$ & $\begin{array}{c}\text { F } \\
\text { Value }\end{array}$ & $\operatorname{Pr}>F$ \\
\hline Natural Community & 1 & 550 & 3.42 & 0.0651 \\
\hline Number of Burns & 4 & 550 & 1.69 & 0.1501 \\
\hline $\begin{array}{c}\text { Natural Community X Number of } \\
\text { Burns(Burn Unit) }\end{array}$ & 67 & 550 & 2.29 & $\begin{array}{c}< \\
0.0001\end{array}$ \\
\hline $\begin{array}{c}\text { Natural Community X Number of } \\
\text { Burns }\end{array}$ & 4 & 550 & 0.70 & 0.5905 \\
\hline
\end{tabular}

Table A8. Type III sum of squares tests for fixed effects used to model fire-tolerant seedling density. For all comparisons, $\alpha=0.05$.

\begin{tabular}{|c|c|c|c|c|}
\hline Effect & $\begin{array}{l}\text { Numerator } \\
\text { DF }\end{array}$ & $\begin{array}{l}\text { Denominator } \\
\text { DF }\end{array}$ & $\begin{array}{c}\mathbf{F} \\
\text { Value }\end{array}$ & $\operatorname{Pr}>\mathbf{F}$ \\
\hline Natural Community & 1 & 1563 & 14.30 & 0.0002 \\
\hline Number of Burns & 4 & 1563 & 7.76 & $\begin{array}{c}< \\
0.0001\end{array}$ \\
\hline $\begin{array}{c}\text { Natural Community X Number of } \\
\text { Burns(Burn Unit) }\end{array}$ & 67 & 1563 & 3.60 & $\begin{array}{c}< \\
0.0001\end{array}$ \\
\hline $\begin{array}{c}\text { Natural Community X Number of } \\
\text { Burns }\end{array}$ & 4 & 1563 & 0.85 & 0.4937 \\
\hline
\end{tabular}




\section{VITA}

Christine Steinwand concurrently finished both a Bachelor of Science in Environmental Science and a Bachelor of Arts in Environmental Policy from Drake University in Des Moines, Iowa in 2009. From there, Christine began her work in Missouri, as a seasonal botanist working for the Missouri Ozark Forest Ecosystem Project. In the fall of 2009, Christine began serving for AmeriCorps St. Louis as a member of the Emergency Response Team. While on ACSTL ERT, Christine traveled throughout Missouri and worked on several conservation projects, including trail maintenance, wild and prescribed fire, and invasive species control. Christine served during the times that tornadoes hit St. Louis and Joplin in 2011, and was instrumental in developing relief efforts in Joplin.

Christine began work on her Master of Science at the University of Missouri during the fall of 2011. As a student, Christine was active in several Mizzou and greater Columbia organizations, including the Mizzou Forestry Graduate Student Association, for which she served as Vice President, and the Mizzou Student Association for Fire Ecology, for which she was treasurer. During the summers of 2012 and 2013, Christine worked with the fire effects crew of the National Park Service at the Ozark National Scenic Riverways in Van Buren, Missouri. Christine will be graduating from Mizzou July 2014 with a Master of Science in Forestry and a certificate in Conservation Biology. 